Review

\title{
On the Structure of Chiral Dirhodium(II) Carboxylate Catalysts: Stereoselectivity Relevance and Insights
}

\author{
Frady G. Adly \\ Biomedical Science Department, Faculty of ESTeM, University of Canberra, Canberra, ACT 2601, Australia; \\ frady.gouany@canberra.edu.au; Tel.: +61-(02)-6206-8963
}

Received: 2 November 2017; Accepted: 17 November 2017; Published: 20 November 2017

\begin{abstract}
Modern experiments have offered alternative interpretations on the symmetry of chiral dirhodium(II) carboxylate complexes and its relationship to their level of enantioselectivity. So, this contribution is to provide an insight on how the knowledge around the structure of these catalysts has evolved with a particular emphasis on the impact of this knowledge on enantioselectivity prediction and catalyst design.
\end{abstract}

Keywords: dirhodium(II) complexes; asymmetric synthesis; chiral catalysis; catalyst design; metal-carbene chemistry; symmetry

\section{Introduction}

Chiral dirhodium(II) paddlewheel complexes are among the most attractive catalysts that found a widespread application in the fields of metal-nitrene and metal-carbene transformations [1-15]. This immense interest originates from their exceptional ability to effectively catalyze a broad spectrum of reactions with high levels of chemo-, regio- and stereo-selectivity. These transformations involve aziridinations [16-18], C-H insertions [7,19,20], ylide transformations [21-25], Lewis acid-promoted reactions [21,26-30], cross-coupling reactions [31], cyclopropanation and cyclopropenation reactions [32-35]. In fact, they have proven their potential, particularly, in the field of asymmetric synthesis. As an example to showcase the utility of these complexes, methyl styryldiazoacetate (1), in the presence of a suitable substrate and a dirhodium(II) catalyst, can undergo a range of chemical transformations including cyclopropanation [36-38], C-H insertion [39,40], Si-H insertion [41], tandem cyclopropanation/Cope rearrangement [42,43], tandem O-H insertion/[2,3] sigmatropic rearrangement [44], vinylogous reactivity [45,46], tandem C-H insertion/Cope rearrangement $[47,48]$, or [3+2] cycloaddition [49] generating a variety of useful synthetic entities in excellent diastereo- and enantioselectivity (Scheme 1).

Chiral dirhodium(II) carboxylate complexes constitute a very important class of dirhodium(II) catalysts. Their structure consists of two rhodium atoms connected together through a unique dirhodium bridge. This dirhodium axes is connected to four chiral electron withdrawing carboxylate ligands and they have two vacant axial positions available for carbene binding $[50,51]$. Although several highly enantioselective dirhodium(II) carboxylate catalysts have been reported to date $[2,52]$ and their application spectrum has expanded dramatically, limited evidence is known on how chirality is tailored at the active center of these complexes by its four chiral carboxylate ligands. As a consequence, this article is providing an insight on how the knowledge around the structure of dirhodium(II) carboxylate complexes has evolved. This is with a particular emphasis on the impact of this knowledge on enantioselectivity prediction and catalyst design. To the best of our knowledge, this topic was last reviewed by Hansen and Davies in 2008 [53] and since then subsequent investigations have offered alternative interpretations on the symmetry of chiral dirhodium(II) carboxylate complexes and its relationship to their level of enantioselectivity. 


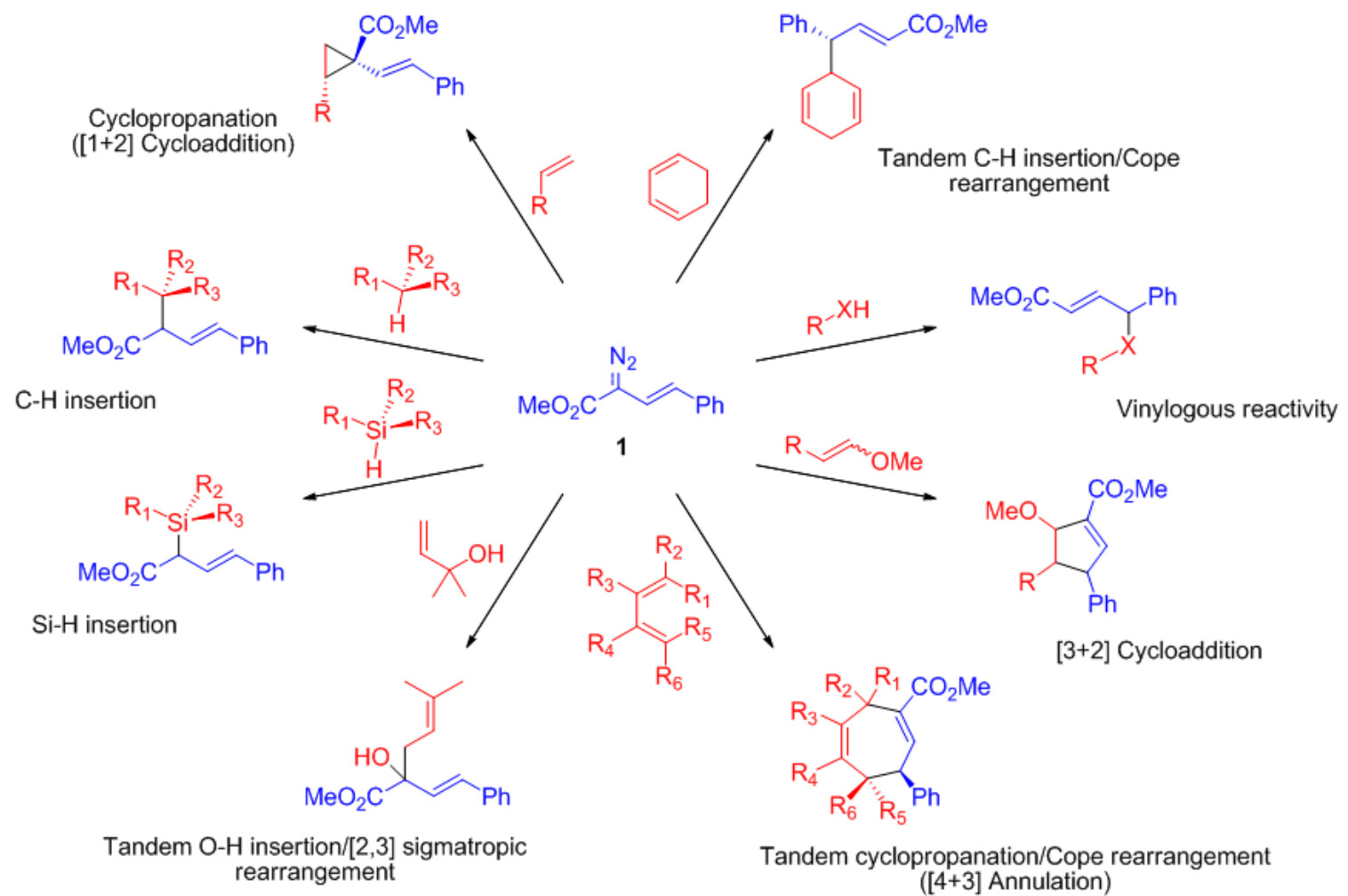

Scheme 1. Dirhodium(II)-mediated chemistry of methyl styryldiazoacetate (1) with different substrates.

\section{Ligand Blocking Groups Arrangements}

Generally for chiral dirhodium(II) carboxylate complexes, it is agreed that the ligand blocking groups can adapt either an up $(\alpha)$ or down $(\beta)$ positions around the catalyst core. It was also assumed that, the ligand's blocking group cannot be situated in the periphery of the dirhodium(II) core as it would bump into the neighboring ligand [36,53]. Thus, by taking into account the $\alpha$ and $\beta$-arrangements for all four ligands, four possible conformations can be mainly considered: $\alpha, \alpha, \alpha, \alpha$ ( $C_{4}$-symmetry), $\alpha, \alpha, \beta, \beta$ ( $C_{2}$-symmetry), $\alpha, \beta, \alpha, \beta$ ( $D_{2}$-symmetry) and $\alpha, \alpha, \alpha, \beta$ ( $C_{1}$-symmetry) (Figure 1) $[2,4,36,53,54]$.

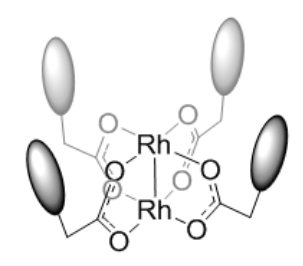

$\alpha, \alpha, \alpha, \alpha\left(C_{4}\right.$-Symmetry $)$

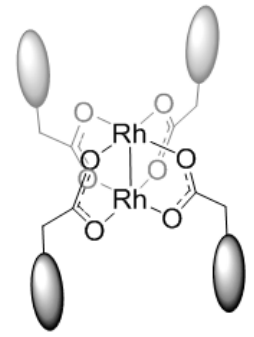

$\alpha, \alpha, \beta, \beta\left(C_{2}\right.$-Symmetry)

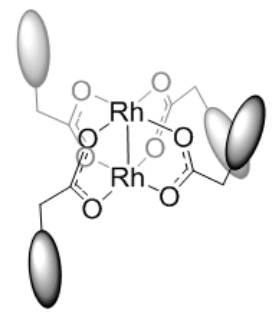

$\alpha, \beta, \alpha, \beta\left(D_{2}\right.$-Symmetry)

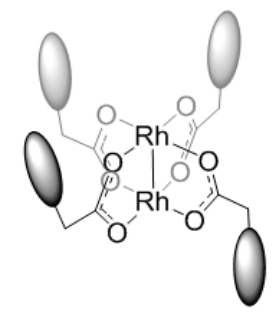

$\alpha, \alpha, \alpha, \beta\left(C_{1}\right.$-Symmetry)

Figure 1. Main arrangements of ligand's blocking groups around the dirhodium(II) core and their point groups (the sterically blocking groups around the rhodium active sites are depicted as ovals) $[2,4,36,53,54]$.

\section{1. $\alpha, \beta, \alpha, \beta$-Conformation}

Initially, Hansen and Davies suggested that catalysts having two different carbene-formation sites should not lead to high enantiocontrol [53]. In other words, complexes with $\alpha, \alpha, \beta, \beta$ - and $\alpha, \beta, \alpha, \beta$-arrangements (having $C_{2}$ - and $D_{2}$-symmetry, respectively) are the only effective catalysts 
in terms of enantioselectivity as they possess two equivalent catalyst faces. While complexes with $\alpha, \alpha, \alpha, \alpha$ - and $\alpha, \alpha, \alpha, \beta$-conformations, which have non-equivalent catalyst faces, are likely to induce low or no enantioinduction as their more accessible and kinetically active face is achiral. This previous proposal from Davies et al. originates from their discovery of $\mathrm{Rh}_{2}$ (S-DOSP) $)_{4}$ catalyst (Scheme 2) [36], which offered extraordinary enantioselectivity in a wide range of chemical transformations (up to $99 \%$ ee) $[7,13,36,40,42,44,47,48,55-68]$. This exceptional enantioselectivity of $\mathrm{Rh}_{2}(S \text {-DOSP })_{4}$ was proposed to originate from a favored $\alpha, \beta, \alpha, \beta$-arrangement of ligands adapted during catalysis. The arrangement that leads to a catalyst with two equivalent rhodium active sites and adequate sterically overburden groups that can limit the trajectories approaching the axial carbene ligand (Scheme 2) $[7,13,36,53]$. For example, low temperature $\mathrm{Rh}_{2}(S \text {-DOSP })_{4}$-catalyzed cyclopropanation of styrene with methyl styryldiazoacetate resulted in the generation of the corresponding cyclopropane product in more than 50:1 E/Z diastereomeric ratio and 98\% ee (Scheme 2a) [13,69]. A general model was then proposed to explain the observed stereochemical outcome $[13,36,68,70]$. In this model, $\mathrm{Rh}_{2}(S \text {-DOSP })_{4}$ is assumed to favor the $\alpha, \beta, \alpha, \beta$-conformation during catalysis at which, the $s i$-face of the metal-carbene complex is protected by a ligand blocking group. The substrate will approach from the re-face to generate the product in the observed absolute configuration (Scheme 2a).

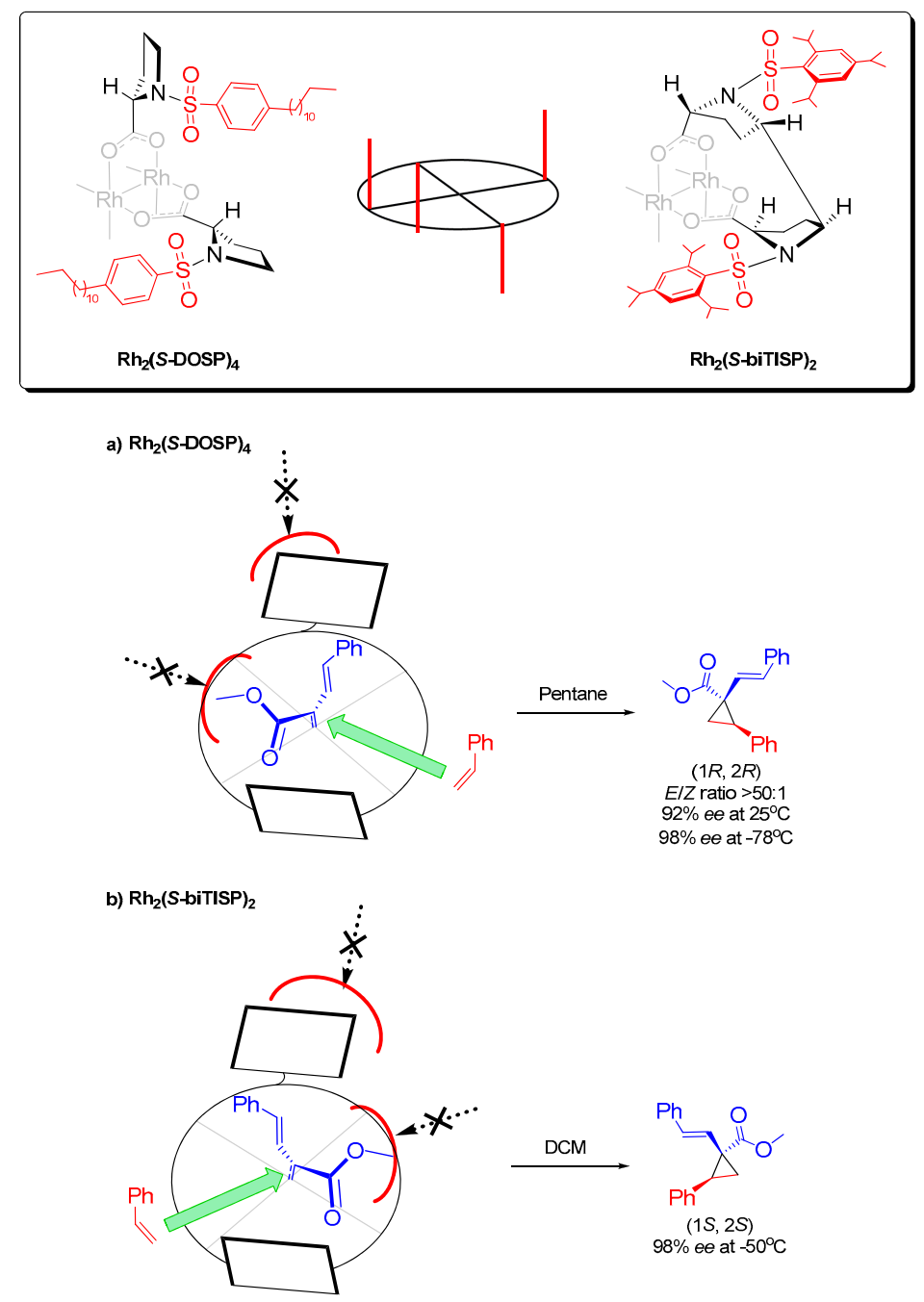

Scheme 2. Structure, $D_{2}$-symmetry and facial enantioselectivity in enantioselective cyclopropanation of styrene with methyl styryldiazoacetate of $\mathrm{Rh}_{2}(S \text {-DOSP })_{4}$ and $\mathrm{Rh}_{2}(S \text {-biTISP })_{2}$ as proposed by Davies et al. (a) $\mathrm{Rh}_{2}(S \text {-DOSP) })_{4}$-catalyzed reaction $[13,36,69]$, (b) $\mathrm{Rh}_{2}(S \text {-biTISP) })_{2}$-catalyzed reaction $[13,71]$. 
To support the $D_{2}$-symmetry hypothesis of $\mathrm{Rh}_{2}(S \text {-DOSP })_{4}$, the authors introduced the second generation prolinate-based complex, $\mathrm{Rh}_{2}\left(\mathrm{~S}\right.$-biTISP) ${ }_{2}$ (Scheme 2) $[13,71,72]$. As the ligands themselves possess a $C_{2}$-symmetry, $\mathrm{Rh}_{2}$ (S-biTISP $)_{2}$ was anticipated to adapt the higher $D_{2}$-symmetrical structure. More importantly, the complex was expected to be more rigid at which, the ligands are conformationally locked in the $\alpha, \beta, \alpha, \beta$-arrangement around the catalyst active centers. For this catalyst, not only both faces are equivalent but also all staggered binding orientations of the axial carbene ligands are identical with respect to the approaching substrate $[13,53,71]$. As expected by the authors, $\mathrm{Rh}_{2}$ (S-biTISP) ${ }_{2}$ demonstrated excellent enantioselectivity in the enantioselective intermolecular cyclopropanation of styrene with methyl styryldiazoacetate leading to the generation of the cyclopropane product in $98 \%$ ee (Scheme $2 b$ ) $[13,71]$. This result very well supported the proposed concept that the observed enantioselectivity of $\mathrm{Rh}_{2}(S \text {-DOSP })_{4}$ originates from an $\alpha, \beta, \alpha, \beta$-conformation adapted during catalysis. However, the use of $\mathrm{Rh}_{2}(S \text {-biTISP })_{2}$ catalyst preferentially resulted in the generation of the $(1 S, 2 S)$-cyclopropane product (Scheme $2 b)$ which was the opposite to that obtained with the $\mathrm{Rh}_{2}(S \text {-DOSP) })_{4}$-catalysed reaction (Scheme $2 \mathrm{a}$ ). The authors returned this difference in asymmetric induction to the different preferred staggered orientation for the carbene binding which causes different channels of the metal-carbene intermediate to be exposed to the approaching alkene [13].

In the same context, $\mathrm{Rh}_{2}(R-B T P C P)_{4}$ was also reported as a catalyst that exhibited high enantioselectivity levels [73-75]. For example, the $\mathrm{Rh}_{2}(R-\mathrm{BTPCP})_{4}$-catalyzed cyclopropanation of styrene with methyl styryldiazoacetate generated the cyclopropane product in $92 \%$ ee [73]. Based on its $X$-ray crystal structure, this enantioselectivity was again returned to the $\alpha, \beta, \alpha, \beta$-distribution of ligands around the dirhodium(II) core (Scheme 3) [73].<smiles>COC(=O)C(=N)/C=C/c1ccccc1</smiles>

$92 \%$ ee

$E / Z$ ratio $>20: 1$

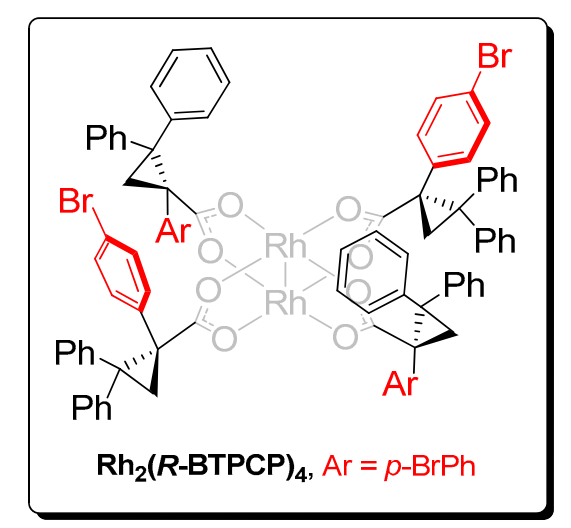

Scheme 3. $\mathrm{Rh}_{2}(R \text {-BTPCP })_{4}$-catalyzed cyclopropanation of styrene with methyl styryldiazoacetate and the $D_{2}$-symmetric structure of $\mathrm{Rh}_{2}(R-\mathrm{BTPCP})_{4}$ according to its X-ray crystal structure [73].

This research was further extended and, very recently, Davies et al. reported its analogue, $\mathrm{Rh}_{2}(R-3,5-(p-t \mathrm{BuPh}) \mathrm{TPCP})_{4}$, as a very successful catalyst in achieving highly regio-, diastereoand enantio-selective $\mathrm{C}-\mathrm{H}$ functionalization at the inactivated $\mathrm{C} 2$ position of $n$-alkanes and terminally substituted $n$-alkyl compounds (Scheme 4) [52]. Again, X-ray crystallography along with computational studies showed that the catalyst disfavors the existence of two adjacent 3,5-di(tert-butylphenyl)phenyl groups on the same face of the catalyst. Hence the preferred orientation of ligands is $\alpha, \beta, \alpha, \beta$ around both catalyst's active sites (Scheme 4) [52]. 

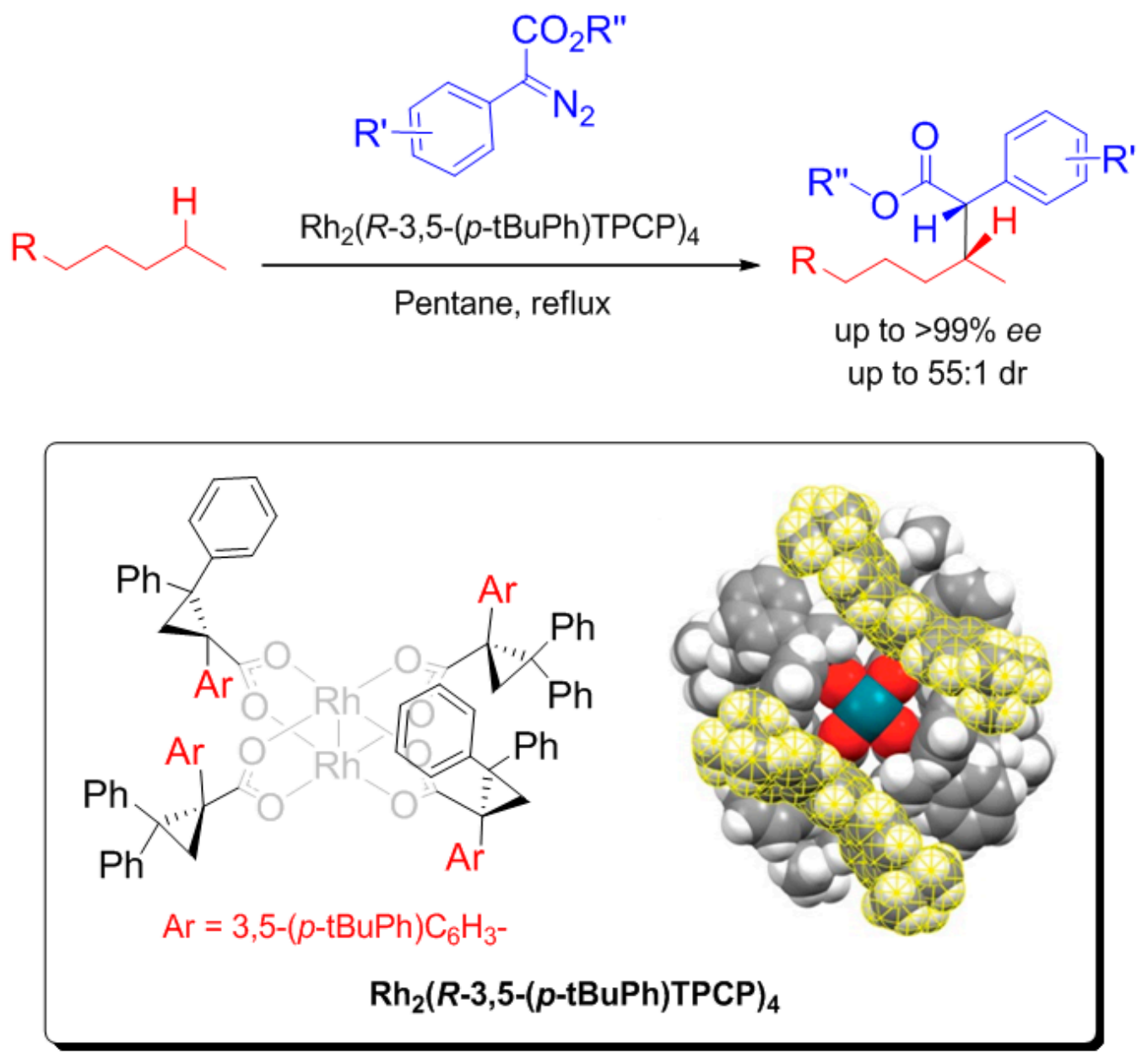

Scheme 4. $\mathrm{Rh}_{2}(R-3,5-\mathrm{di}(p-\mathrm{tBuPh}) \mathrm{TPCP})_{4}$-catalysed C-H functionalization of pentane and substituted $n$-alkanes and the $D_{2}$-symmetric structure of the catalyst according to its $X$-ray crystal structure. The two 3,5-di $(p-t \mathrm{BuPh}) \mathrm{C}_{6} \mathrm{H}_{3}$-groups are highlighted in yellow. (X-ray crystal structure adapted with permission from Macmillan Publishers Ltd.: Liao, K.; Negretti, S.; Musaev, D.G.; Bacsa, J.; Davies, H.M.L. Nature 2016, 533, 230-234, Copyright 2017).

\section{2. $\alpha, \alpha, \beta, \beta$ - and $\alpha, \alpha, \alpha, \alpha$-Conformations}

\subsubsection{Global Catalyst Symmetry}

The previous proposal that only catalysts with $D_{2}$ - and $C_{2}$-symmetric structures are effective in terms of enantiocontrol [53] relied also on Hashimoto's reports for $\mathrm{Rh}_{2}(S-P T T L)_{4}$. In 1993, Hashimoto, Ikegami and co-workers first reported their famous complex, $\mathrm{Rh}_{2}(\mathrm{~S}-\mathrm{PTTL})_{4}$ [76,77], as a catalyst that manifested (along with its variants) high enantioselectivity levels in wide range of organic transformations [2,54,78-84]. For example, in enantioselective [2,3]-sigmatropic rearrangement of the cyclic propargylic oxonium ylide shown in Scheme $5 \mathrm{a}, \mathrm{Rh}_{2}(S-\mathrm{PTTL})_{4}$ provided the best enantioselectivity of $79 \%$ ee of the corresponding allenic bearing benzofuran-3-one product (Scheme 5a) [85].

Hashimoto et al. initially proposed that $\mathrm{Rh}_{2}(\mathrm{~S} \text {-PTTL })_{4}$ favors the $\alpha, \alpha, \beta, \beta$-conformation during catalysis. This assumption was based on the $\mathrm{X}$-ray crystal structure of its analogue, $\mathrm{Rh}_{2}(\mathrm{~S}-\mathrm{PTPA})_{4}$, which also showed moderate to good enantioselectivity in some asymmetric transformations $[76,79,85,86]$. For example, in aromatic C-H insertion of $\alpha$-diazoketones, $\mathrm{Rh}_{2}(\mathrm{~S} \text {-PTPA })_{4}$ resulted into the formation of the corresponding 1-alkyl-1-phenyl-2-indanones in up to 95\% ee (Scheme 5b) [86]. The X-ray crystal 
structure of $\mathrm{Rh}_{2}(S \text {-PTPA })_{4}$ showed that the catalyst is adapting the $\alpha, \alpha, \beta, \beta$-conformation in solid state (Scheme 5b) [76,85-87].

Based on Hashimoto's hypothesis, a general model was proposed to account for the observed enantioselectivity with $\mathrm{Rh}_{2}(S-\mathrm{PTTL})_{4}[85,86,88,89]$. In this model, it was proposed that $\mathrm{Rh}_{2}(S-\mathrm{PTTL})_{4}$ preferentially adapts the $\alpha, \alpha, \beta, \beta$-conformation during catalysis. The carbene orients itself at which, its bulky side is directed away from the catalyst walls (Scheme $5 \mathrm{a}$ ). The substrate approaches from the $r$-face to generate the product in the observed absolute configuration.

a) $\mathrm{Rh}_{2}(\mathrm{~S}-\mathrm{PTTL})_{4}$<smiles>C#CCOc1c(C)cccc1C(=O)C(=N)C(=O)OC</smiles><smiles>C=CC1(C(=O)OC)Oc2ccccc2C1=O</smiles>

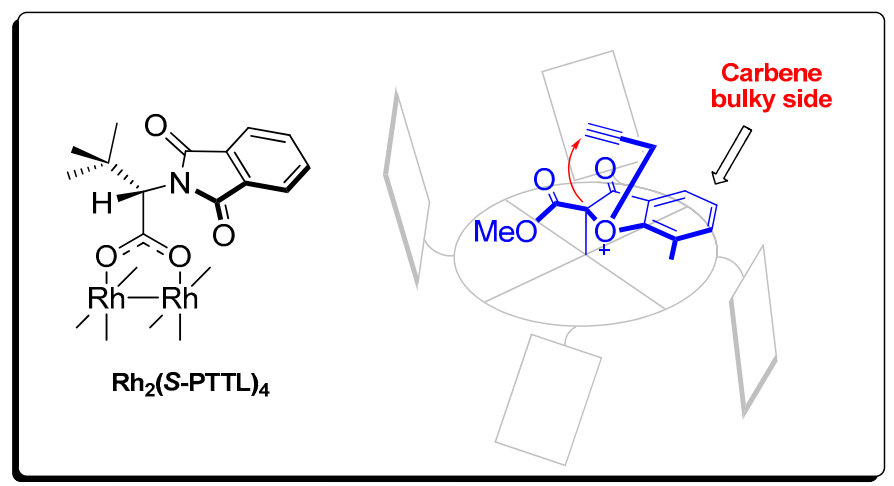

b) $\mathrm{Rh}_{2}(\mathrm{~S}-\mathrm{PTPA})_{4}$

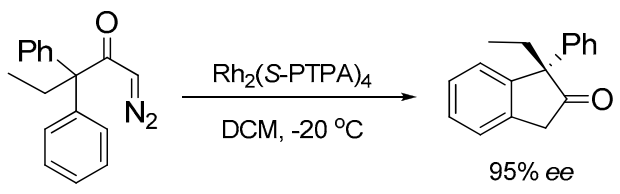

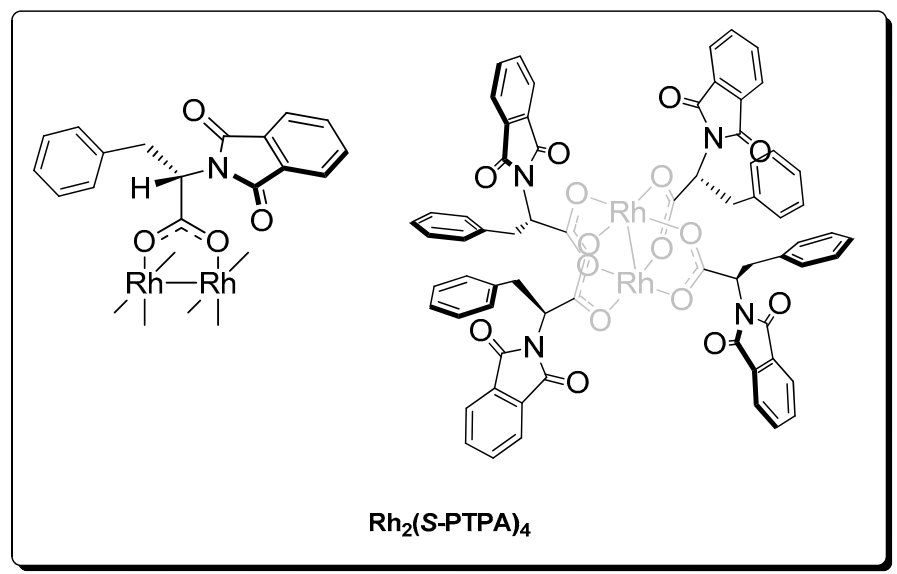

Scheme 5. (a) $\mathrm{Rh}_{2}(S \text {-PTTL })_{4}$-catalyzed enantioselective tandem propargylic oxonium ylide formation/[2,3]-sigmatropic rearrangement (Facial selectivity of the $\mathrm{Rh}_{2}(S \text {-PTTL })_{4}$-stabilized carbene according to the model proposed by Hashimoto et al. [85]); (b) $\mathrm{Rh}_{2}(S \text {-PTPA) })_{4}$-catalyzed enantioselective aromatic $\mathrm{C}-\mathrm{H}$ insertion reaction and the $\mathrm{C}_{2}$-symmetric structure of the catalyst according to its reported X-ray crystal structure [76,85-87]. 
Later, Davies et al. noticed that, in some reactions, the steric bulk of the ligand affects the enantioselectivity of the catalyst at which the enantioselectivity increased by increasing the steric bulk at the $\alpha$-carbon of the ligands. For example, in dirhodium(II)-catalyzed enantioselective tandem carbonyl ylide formation/intermolecular 1,3-dipolar cycloaddition of $\alpha$-diazoketones, the best enantioselectivity was observed when $\mathrm{Rh}_{2}(\mathrm{~S}-\mathrm{PTTL})_{4}$ was used as a catalyst $(74 \% e e)$, followed by $\mathrm{Rh}_{2}(\mathrm{~S}-\mathrm{PTV})_{4}(51 \%$ ee $)$ and $\mathrm{Rh}_{2}(\mathrm{~S}-\mathrm{PTA})_{4}(35 \%$ ee) [90] (Scheme 6a). As a consequence, Davies et al. suggested that the logical way to further develop the $\mathrm{Rh}_{2}(S-\mathrm{PTTL})_{4}$ catalyst is to substitute the tert-butyl group connected to the $\alpha$-carbon with a much bulkier hydrocarbon group. Accordingly, they introduced $\mathrm{Rh}_{2}(\mathrm{~S}-\mathrm{PTAD})_{4}$ catalyst which is derived from L-adamantylglycine ligands (Scheme 6b) [37]. As expected, this catalyst succeeded to afford enantioselectivity levels superior to $\mathrm{Rh}_{2}(S-\mathrm{PTTL})_{4}$ in different asymmetric transformations [37,88,91-95]. For example, $\mathrm{Rh}_{2}(S \text {-PTAD })_{4}$-catalyzed cyclopropanation of styrene with $\alpha$-diazobenzylphosphonate resulted into the generation of the corresponding cyclopropylphosphonate product in high levels of enantioselectivity $\left(99 \%\right.$ ee) compared to $\mathrm{Rh}_{2}(\mathrm{~S} \text {-DOSP })_{4}(34 \% e e), \mathrm{Rh}_{2}(\mathrm{~S} \text {-biTISP })_{2}$ (88\% ee) and $\mathrm{Rh}_{2}(\mathrm{~S}-\mathrm{PTTL})_{4}(97 \%$ ee) (Scheme $6 \mathrm{~b})$ [37].

a)
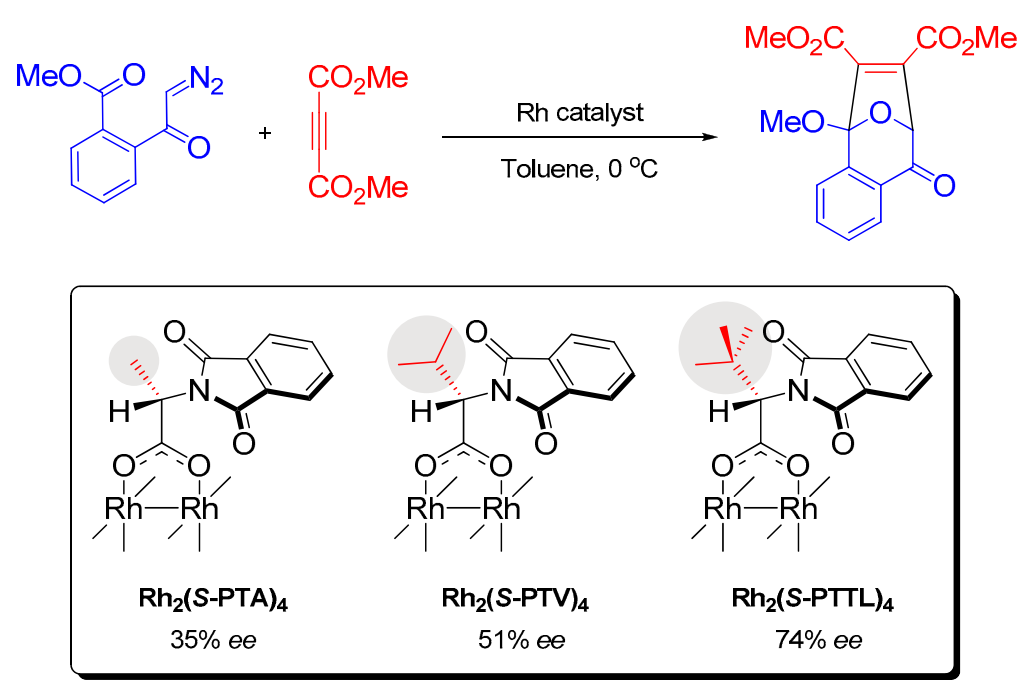

b)
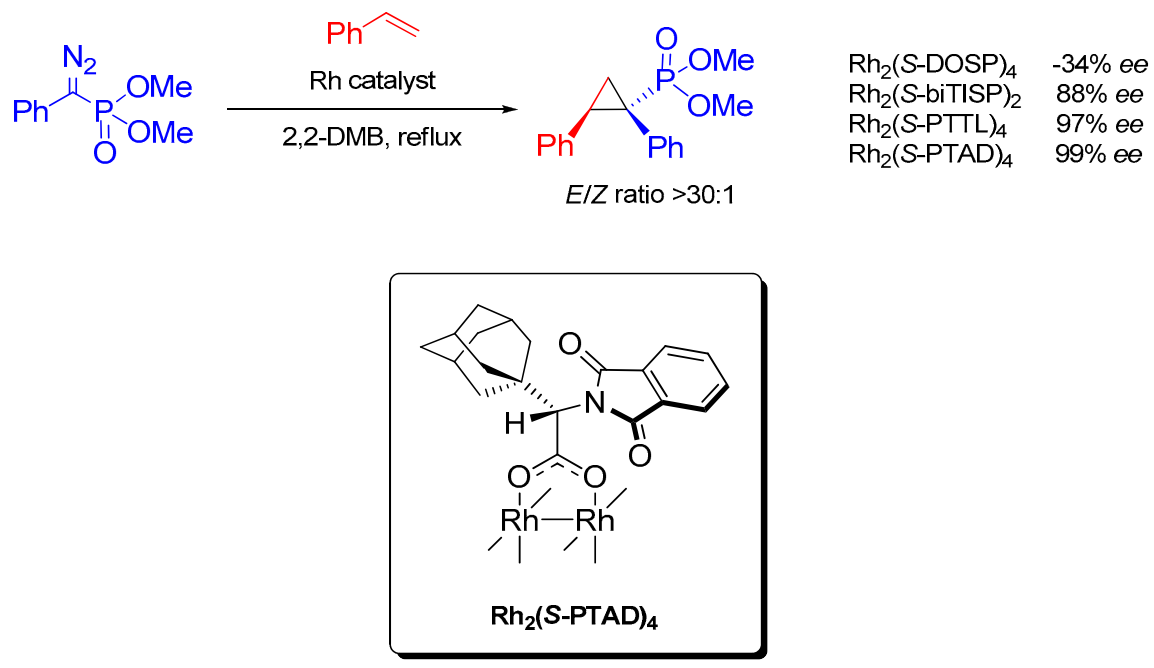

Scheme 6. (a) Dirhodium(II)-catalyzed enantioselective tandem carbonyl ylide formation/intermolecular 1,3-dipolar cycloaddition of $\alpha$-diazoketones [90]; (b) $\mathrm{Rh}_{2}\left(S\right.$-PTAD) ${ }_{4}$-catalyzed enantioselective synthesis of dimethyl 1,2-diphenylcyclopropylphosphonate [37]. 
Up to this point, Hansen and Davies theoretical assumption that only catalysts with $\alpha, \alpha, \beta, \beta$ - and $\alpha, \beta, \alpha, \beta$-arrangements results in high enantioselectivity and not the others [53] was very well supported by scientific evidence. Nevertheless in 2009, Fox et al. were able to capture an X-ray crystal structure for $\mathrm{Rh}_{2}(S-\mathrm{PTTL})_{4}[78,87]$. Surprisingly, the obtained structure revealed that the catalyst is adapting the $\alpha, \alpha, \alpha, \alpha$-conformation in solid state and not the expected $\alpha, \alpha, \beta, \beta$-conformation (Figure 2). Furthermore, the structure showed that the catalyst is having a rectangular chiral cavity $\left(C_{2}\right.$ - rather than $C_{4}$-symmetry) with only one ethyl acetate axial ligand coordinated to the rhodium atom from the cavity face.

a)

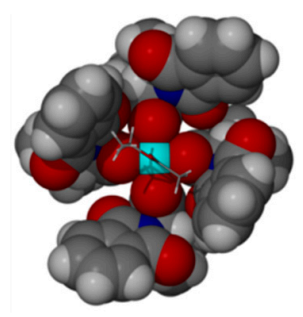

b)
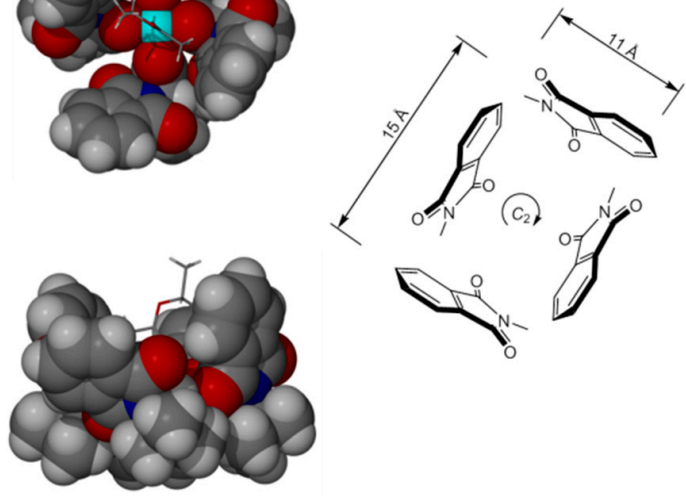

Figure 2. (a) Space filling structure of mono(EtOAc) adduct of $\mathrm{Rh}_{2}(S$-PTTL) 4 (top view); Schematic illustration of the rectangular binding pocket of $\mathrm{Rh}_{2}(\mathrm{~S}-\mathrm{PTTL})_{4} ;$ (b) Space filling structure of mono(EtOAc) adduct of $\mathrm{Rh}_{2}$ (S-PTTL) 4 (side view). (Adapted from Adly, F.G.; Gardiner, M.G.; Ghanem, A. Chem. Eur. J. 2016, 22, 3447, Copyright 2017, with permission from John Wiley and Sons).

Based on the new information, Fox et al. introduced a new model to account for the enantioselectivity exhibited by $\mathrm{Rh}_{2}$ (S-PTTL $)_{4}$ in enantioselective cyclopropanation of styrene with $\alpha$-alkyldiazoesters (Scheme 7) [78,87]. In this model, $\mathrm{Rh}_{2}(S \text {-PTTL) })_{4}$ was proposed to keep its $\alpha, \alpha, \alpha, \alpha$-conformation during catalysis and the carbene is anticipated to align itself within the wide dimension of the catalyst's rectangular cavity leaving its si-face accessible by the substrate. Also according to Fox model, the tert-butyl groups are crucial to restrict the reactivity to the chiral cavity face of the catalyst and limit the racemic background reaction.

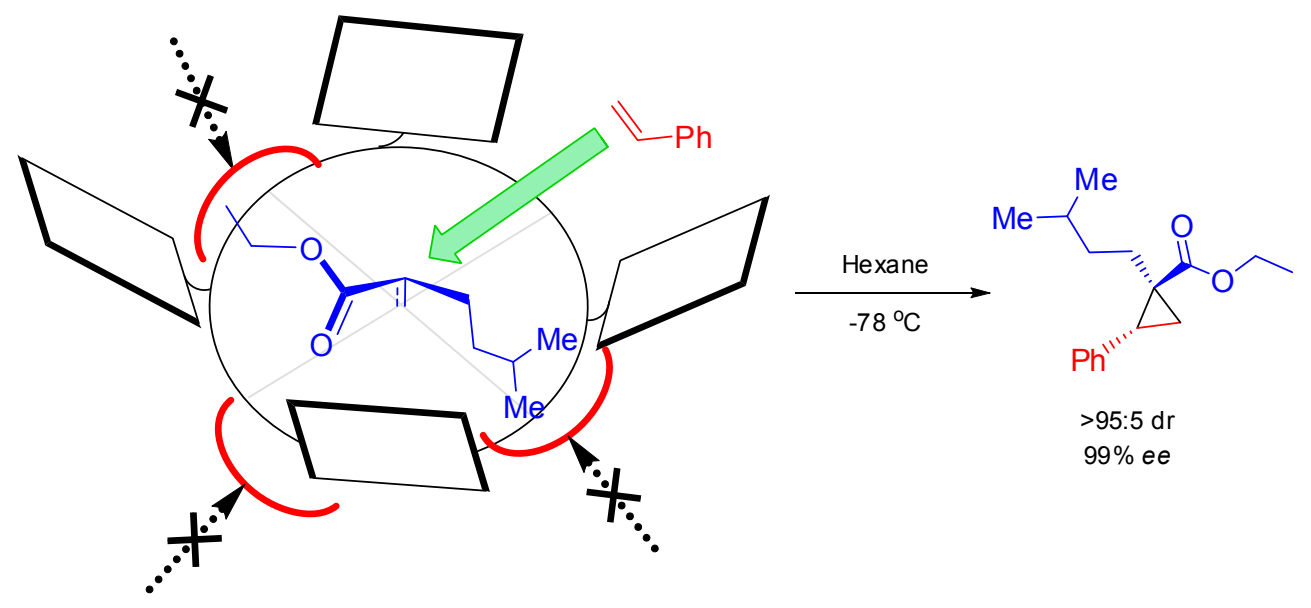

Scheme 7. Facial selectivity of the $\mathrm{Rh}_{2}(S \text {-PTTL })_{4}$-stabilized carbene according to the model proposed by Fox et al. [78,87]. 
Fox model was very well supported by the results obtained earlier for $\mathrm{Rh}_{2}(S-\mathrm{PTAD})_{4}$ by being more enantioselective than $\mathrm{Rh}_{2}(\mathrm{~S}-\mathrm{PTTL})_{4}[37,91-93,95,96]$. The results were very relevant as the much bulkier adamantyl groups would more efficiently block the carbene ligands from coordinating to the achiral rhodium face (shrouded by the adamantly groups) compared to the tert-butyl groups of $\mathrm{Rh}_{2}(S-P T T L)_{4}$ leading to the observed more enantioselective outcome. Moreover, Fürstner et al. recently succeeded in capturing an X-ray crystal structure of the $\mathrm{Rh}_{2}(S-\mathrm{PTTL})_{4}=\mathrm{C}\left(\mathrm{MeOC}_{6} \mathrm{H}_{4}\right) \mathrm{CO}_{2} \mathrm{Me}$ intermediate (Figure 3) [97]. The obtained structure showed that the entire carbene resides within a long narrow pocket formed by the four $N$-phthalimido groups of $\mathrm{Rh}_{2}(S-\mathrm{PTTL})_{4}$, that adapt an $\alpha, \alpha, \alpha, \alpha$-arrangement ( $C_{2}$-symmetric). The overall situation looked, therefore, in good agreement with the model proposed by Fox. But, low temperature NMR data for this intermediate returned a single set of signals for the four chiral carboxylate ligands [97]. This observation was not in a good accord with a $C_{2}$-symmetric binding site as proposed by the Fox model.

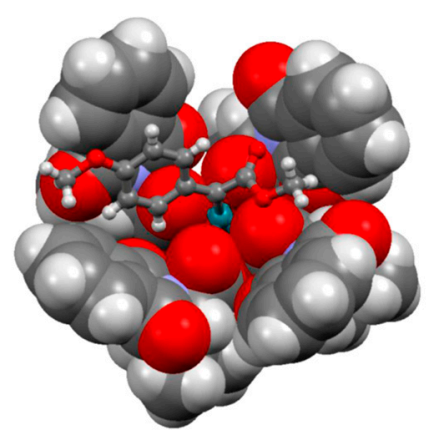

Figure 3. Space-filling model of the $\mathrm{Rh}_{2}(\mathrm{~S} \text {-PTTL })_{4}=\mathrm{C}\left(\mathrm{MeOC}_{6} \mathrm{H}_{4}\right) \mathrm{CO}_{2} \mathrm{Me}$ unit (top view). (Reprinted from Werlé, C.; Goddard, R.; Philipps, P.; Farès, C.; Fürstner, A. Angew. Chem. Int. Ed. 2016, 55, 10760, Copyright 2017, with permission from John Wiley and Sons).

Fox proposal was also challenged by data reported from different research groups. Adly, Ghanem and co-workers reported the X-ray crystal structure of $\mathrm{Rh}_{2}(S-P T A D)_{4}$ [98]. Similar to $\mathrm{Rh}_{2}(S \text {-PTTL })_{4}$, the obtained structure showed that the catalyst is adapting the $\alpha, \alpha, \alpha, \alpha$-conformation in solid state, however, the catalyst was observed to form a bis(EtOAc) adduct when crystalized from ethyl acetate $/ n$-hexane (Figure 4 ). This observation contradicted with the assumption proposed by Fox et al. in their model and confirmed that the adamantyl groups are not completely blocking the "achiral" catalyst face. In other words, there is still enough room for a Lewis basic ligand to coordinate to the achiral axial rhodium site. This observation provided direct evidence that both $\mathrm{Rh}$ atoms are still accessible by the diazo substrates even after the introduction of the bulkier adamantyl groups [98]. In addition, results have shown that complexes with tert-butyl groups at their $\alpha$-carbon produced enantioselectivity levels similar and sometimes higher than $\mathrm{Rh}_{2}(\mathrm{~S} \text {-PTAD })_{4}$ which carries the bulkier adamantyl groups [98].

Also, different reported observations confirmed the flexibility of the PTTL ligands around the rhodium active center, especially in solution and emphasized the effect of the shape and size of the axial ligand on the overall structure of the dirhodium(II)-carbene intermediate. For example, 2D heteronuclear NOESY data reported by the groups of Charette [54] and Duddeck [99], independently, confirmed that $\mathrm{Rh}_{2}(\mathrm{~S}-\mathrm{PTTL})_{4}$ and analogues have a mobile conformation in solution. This confirms the existence of other conformers with at least one $N$-phthalimido group is flipped downward. Further and based on X-ray crystallographic data, $\mathrm{Rh}_{2}(\mathrm{~S}-\mathrm{PTTL})_{4}\left(\mathrm{NC}-\mathrm{C}_{6} \mathrm{H}_{4}-\mathrm{CN}\right)$ adduct was found to adapt a conformation in which one of the ligands is twisted by only about $80^{\circ}$ in solid state [87]. In other words, the ligand's blocking group lies in the periphery of the catalyst, the case that was originally supposed to be problematic due to steric constraints $[36,53]$. Gardiner and Ghanem [2,100] also succeeded to grow crystals of $\mathrm{Rh}_{2}(\mathrm{~S}-\mathrm{PTPA})_{4}(\mathrm{EtOAc})_{2}$ and $\mathrm{Rh}_{2}(\mathrm{~S}-\mathrm{PTPA})_{4}(\mathrm{MeOH})\left(\mathrm{H}_{2} \mathrm{O}\right)$ and they found that different conformations exist for each of these adducts 
at which, all of them feature inequivalent axial coordination sites unlike its original $\alpha, \alpha, \beta, \beta$-structure previously reported by Hashimoto [76,85-87]. The $\mathrm{Rh}_{2}(S-\mathrm{PTPA})_{4}(\mathrm{EtOAc})_{2}$ adduct exhibited an $\alpha, \alpha, \alpha, \beta$-conformation, while $\mathrm{Rh}_{2}(S \text {-PTPA })_{4}(\mathrm{MeOH})\left(\mathrm{H}_{2} \mathrm{O}\right)$ adduct exhibited an $\alpha, \alpha, \alpha, \alpha$-conformation in solid state.

a)

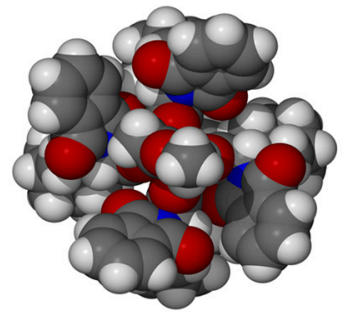

b)

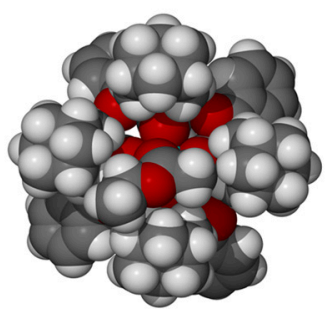

c)

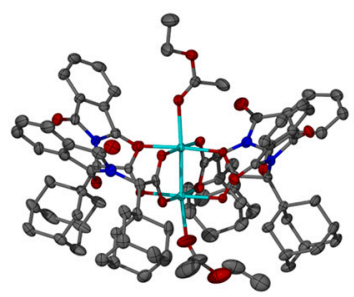

Figure 4. Space filling structure of bis(EtOAc) adduct of $\mathrm{Rh}_{2}(\mathrm{~S}-\mathrm{PTAD})_{4}$ viewed along the $\mathrm{Rh}-\mathrm{Rh}$ axis (a) into the chiral crown cavity, (b) onto the achiral Rh coordination site shrouded by the adamantyl groups. (c) Side view of bis(EtOAc) adduct of $\mathrm{Rh}_{2}(\mathrm{~S}-\mathrm{PTAD})_{4}$. (Adapted from Adly, F.G.; Gardiner, M.G.; Ghanem, A. Chem. Eur. J. 2016, 22, 3447, Copyright 2017, with permission from John Wiley and Sons).

\subsubsection{Local Ligand Symmetry}

Following the classical way of catalyst design, all reported chiral dirhodium(II) carboxylate complexes derived from L-amino acid ligands were designed to have a symmetric $N$-protecting groups for the construction of the chiral ligands [4,53]. However in 2004, Müller and Ghanem reported several $\mathrm{Rh}_{2}(\mathrm{~S} \text {-NTTL })_{4}$ analogues at which, one hydrogen on the $\mathrm{N}$-protecting group is substituted to generate catalysts carrying asymmetric $N$-protecting groups for asymmetric cyclopropanation of styrene with dimethyl malonate [101] and Meldrum's acid [102] (Scheme 8). The authors were surprised when screening results revealed that $\mathrm{Rh}_{2}(S-4-\mathrm{Br}-\mathrm{NTTL})_{4}$-catalyzed cyclopropanation proceeded with far improved levels of enantioselectivity compared to $\mathrm{Rh}_{2}(S-\mathrm{NTTL})_{4}$.

Unfortunately, the authors had no success in growing X-ray quality crystals for $\mathrm{Rh}_{2}(S-4-\mathrm{Br}-\mathrm{NTTL})_{4}$. Instead, the X-ray crystal structure of $\mathrm{Rh}_{2}(\mathrm{~S}-\mathrm{NTTL})_{4}$ (Figure 5) was used as a model to account for the enhanced enantioselectivity that accompanied $\mathrm{Rh}_{2}(S-4-\mathrm{Br}-\mathrm{NTTL})_{4}$ [102]. The authors proposed that, if $\mathrm{Rh}_{2}$ (S-4-Br-NTTL) 4 is retaining a similar structure to $\mathrm{Rh}_{2}(S-\mathrm{NTTL})_{4}$ during catalysis (following Fox et al. proposal), the bromo-substituents would be situated at the cavity rim and are likely to exert a strong influence on the enantiofacial discrimination of the approaching substrate leading to the observed enhanced enantioselectivity. The authors also returned the improved performance of the $4-\mathrm{Br}$ substituted catalyst over the $4-\mathrm{Cl}$ analogue to the size of the substituents. The larger bromosubstituents are expected to exert more influence at the cavity rim leading to higher enantioselectivity in the case of $\mathrm{Rh}_{2}(\mathrm{~S}-4-\mathrm{Br}-\mathrm{NTTL})_{4}$.

Later, Adly and Ghanem investigated this further and they introduced a new approach for the design of dirhodium(II) carboxylate complexes. This approach is through the reduction of the $\mathrm{N}$-protecting group symmetry by the inclusion of a bulky substituent at the catalyst's cavity rim. By the application of their new approach, the authors were able to introduce their catalyst, $\mathrm{Rh}_{2}\left(S_{-}{ }^{\text {tert }} \text { PTTL }\right)_{4}$ (Scheme 9) $[89,98,103]$. For this catalyst, the planarity of the $\mathrm{N}$-phthalimido groups is maintained but the local symmetry of the $N$-protecting group was reduced from $\mathrm{C}_{2 v}$ to $\mathrm{C}_{S}$ by virtue of the substituents. Screening of $\mathrm{Rh}_{2}\left(S_{-}{ }^{\text {tert }} \mathrm{PTTL}\right)_{4}$ in different enantioselective cyclopropanation 
reactions demonstrated that, generally, $\mathrm{Rh}_{2}\left(S_{-}{ }^{\text {tert }} \mathrm{PTTL}\right)_{4}$ is more enantioselective than $\mathrm{Rh}_{2}(S \text {-PTTL })_{4}$, while returning comparable enantioselectivity to $\mathrm{Rh}_{2}(\mathrm{~S}-\mathrm{PTAD})_{4}$ (Scheme 9) [98].
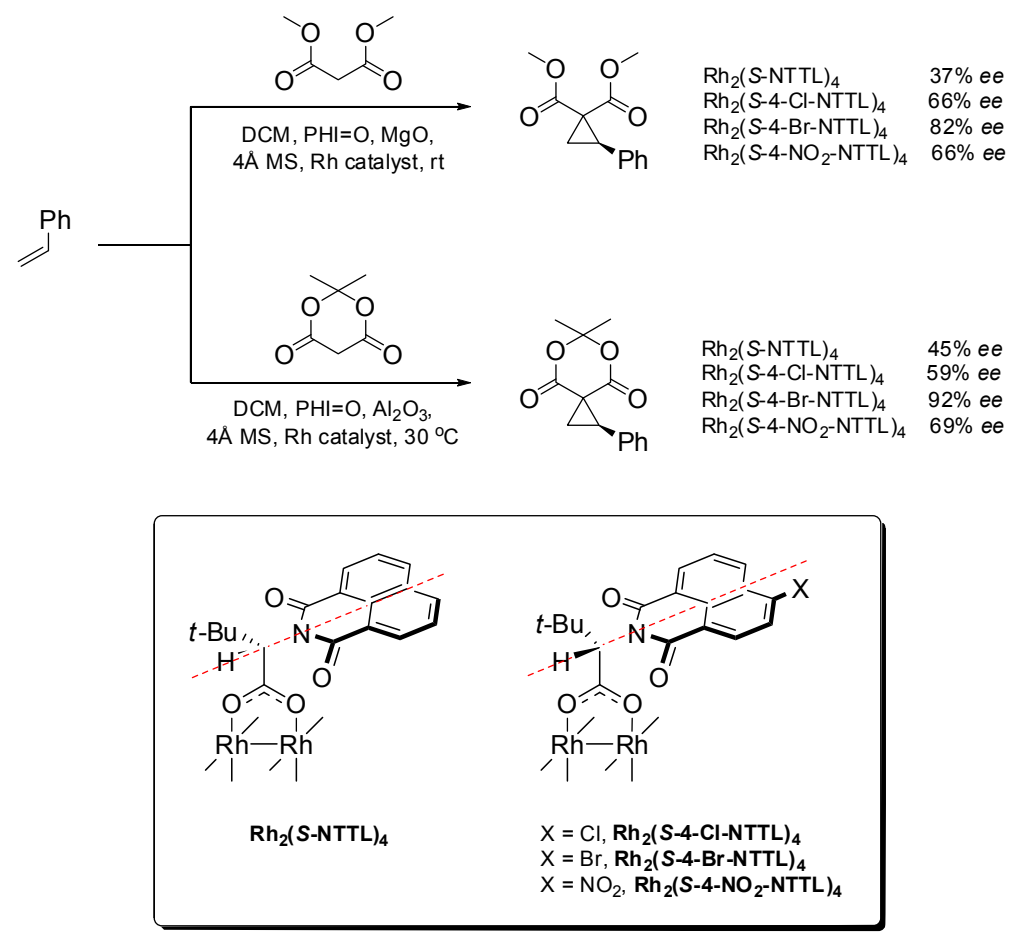

Scheme 8. Dirhodium(II)-catalyzed enantioselective cyclopropanation of styrene with dimethyl malonate [101] and Meldrum's acid [102].

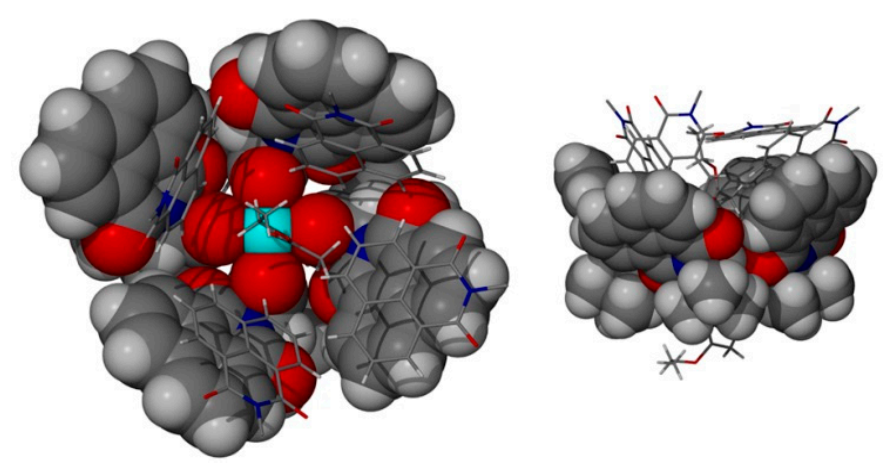

Figure 5. Space filling structure of bis(EtOAc) adduct of $\mathrm{Rh}_{2}(\mathrm{~S}-\mathrm{NTTL})_{4}$ (top and side view). (Reprinted from Ghanem, A.; Gardiner, M.G.; Williamson, R.M.; Müller, P. Chem. Eur. J. 2010, 16, 3291, Copyright 2017, with permission from John Wiley and Sons).

The X-ray crystal structure of $\mathrm{Rh}_{2}\left(S_{-}{ }^{\text {tert }} \mathrm{PTTL}\right)_{4}$ showed that the catalyst is adapting the $\alpha, \alpha, \alpha, \alpha$-conformation in solid state (Scheme 9) featuring the tert-butyl substituents similarly disposed towards the "corner" of the nearly square-shaped cavity. The cavity is approximately square if compared to the reported structure of $\mathrm{Rh}_{2}(\mathrm{~S} \text {-PTTL })_{4}$. The authors claimed that the added tert-butyl substituent on the $\mathrm{N}$-phthalimido group in $\mathrm{Rh}_{2}\left(\mathrm{~S}_{-}{ }^{\text {tert }} \mathrm{PTTL}\right)_{4}$ reinforced the overall chiral twist of the cavity, while, at the same time, not placing added steric hindrance to the binding of axial carbene ligand [98]. The authors proposed that, if this geometry is relevant during catalysis, it is likely to be the reason for the observed enhanced enantioselectivity relative to its parent, $\mathrm{Rh}_{2}(S-\mathrm{PTTL})_{4}$. 

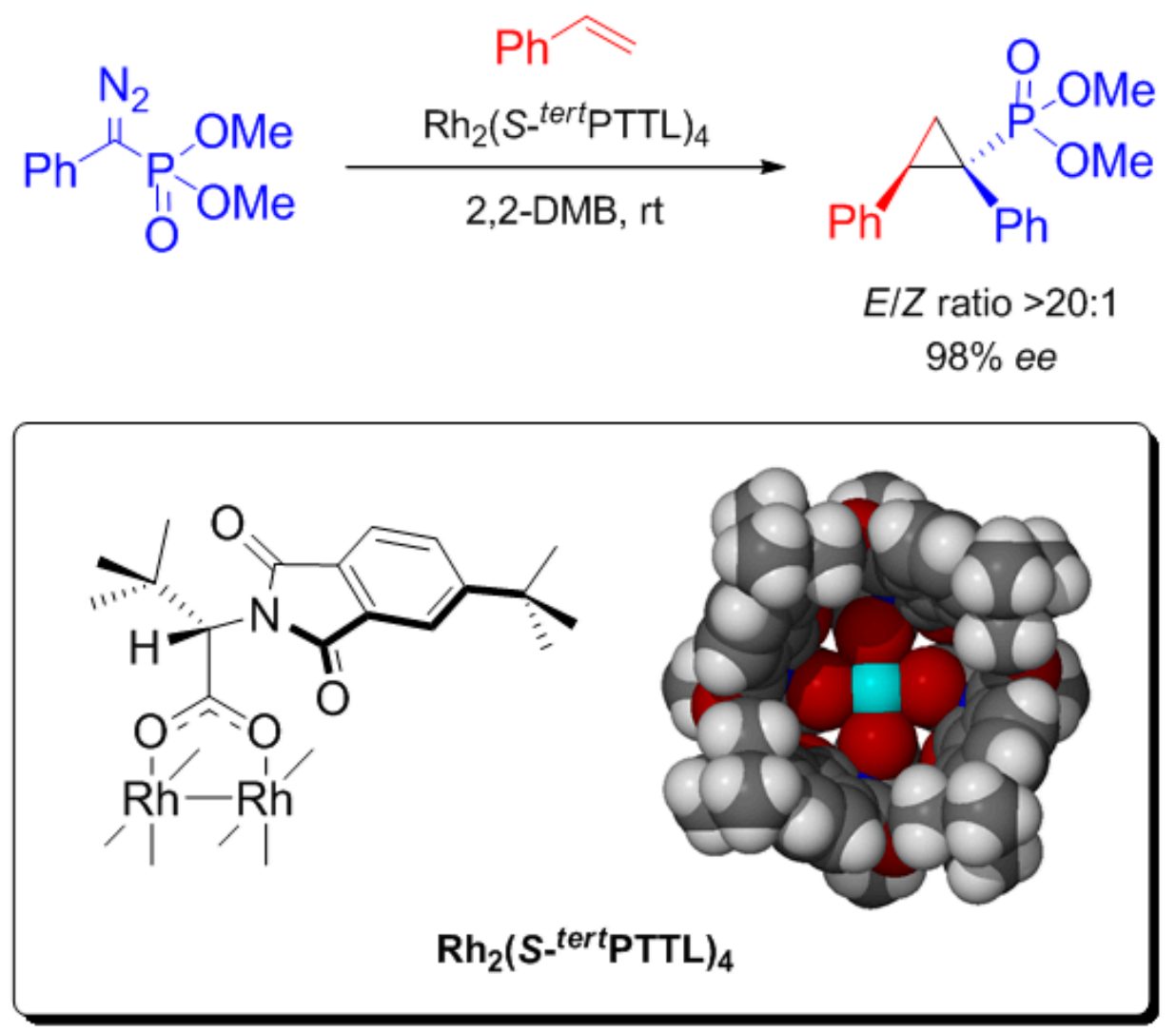

Scheme 9. $\mathrm{Rh}_{2}\left(S_{-}{ }^{\text {tert }} \mathrm{PTTL}\right)_{4}$-catalyzed enantioselective synthesis of dimethyl 1,2diphenylcyclopropylphosphonate and X-ray crystal structure of $\mathrm{Rh}_{2}\left(S_{-}{ }^{\text {tert }} \mathrm{PTTL}\right)_{4}$ (top view). (X-ray crystal structure adapted from Adly, F.G.; Gardiner, M.G.; Ghanem, A. Chem. Eur. J. 2016, 22, 3447, Copyright 2017, with permission from John Wiley and Sons).

\section{3. $\alpha, \alpha, \alpha, \beta$-Conformation}

In 2012, Charette et al. explored the replacement of one of the ligands of $\mathrm{Rh}_{2}(\mathrm{~S} \text {-TCPTTL })_{4}$ (the chlorinated version of $\mathrm{Rh}_{2}(\mathrm{~S} \text {-PTTL })_{4}$ ) with $\mathrm{N}$-phthalimido-2-aminoisobutyric acid ligand (PTAiB). This led to the generation of the lower symmetry heteroleptic complex, $\mathrm{Rh}_{2}(S-\mathrm{TCPTTL})_{3}(\mathrm{PTAiB})$ [104]. The X-ray crystal structure of this complex revealed that it is adapting the $\alpha, \alpha, \alpha, \beta$-conformation in solid state (Scheme 10). Surprisingly, screening results demonstrated that lowering the global symmetry of the catalyst had a beneficial impact on its enantioselectivity. In the cyclopropanation reaction of alkenes with $\alpha$-nitro diazoacetophenones, $\mathrm{Rh}_{2}(\mathrm{~S} \text {-TCPTTL })_{3}$ (PTAiB) resulted into the formation of the cyclopropane product in $96.4 \%$ ee which was higher compared to its parent $\mathrm{Rh}_{2}(\mathrm{~S} \text {-TCPTTL })_{4}(92.4 \%$ ee $)$ (Scheme 10).

Also in the same year, Fox et al. reported the mixed ligated complex, $\mathrm{Rh}_{2}(\mathrm{~S}-\mathrm{PTTL})_{3}(\mathrm{TPA})$ (Scheme 11) [105]. The X-ray crystal structure of this complex showed that all of the $N$-phthalimido groups are on one face of the complex in a structural similarity to $\mathrm{Rh}_{2}(S-\mathrm{PTTL})_{4}$ but with an incomplete chiral pocket (analogous to an $\alpha, \alpha, \alpha, \beta$-arrangement). $\mathrm{Rh}_{2}$ (S-PTTL) 3 (TPA) returned its best enantioselectivity in the cyclopropanation of styrene with ethyl $\alpha$-diazobutanoate $(88 \% e e)$ which was higher than the observed enantioselectivity with $\mathrm{Rh}_{2}(S-P T T L)_{4}$ in the same reaction (79\% ee) (Scheme 11). The scope of this catalyst was expanded to include other substrate classes, namely aliphatic alkynes, silylacetylenes and $\alpha$-olefins, that were particularly challenging in intermolecular cyclopropanations with $\alpha$-alkyl- $\alpha$-diazoesters. Generally, $\mathrm{Rh}_{2}(\mathrm{~S} \text {-PTTL })_{3}(\mathrm{TPA})$ was able to catalyze enantioselective cyclopropanations returning yields and enantioselectivities comparable and sometimes higher than $\mathrm{Rh}_{2}(\mathrm{~S}-\mathrm{PTTL})_{4}$ [105]. 


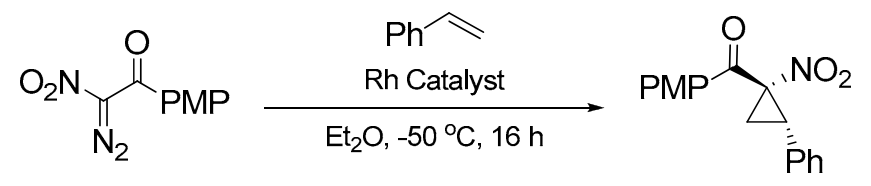

$\begin{array}{ll}\mathrm{Rh}_{2}(\mathrm{~S}-\mathrm{TCPTTL})_{4} & 92.9 \% \text { ee } \\ \mathrm{Rh}_{2}(\mathrm{~S} \text {-TCPTTL })_{3}(\mathrm{PTAiB}) & 96.4 \% \text { ee }\end{array}$

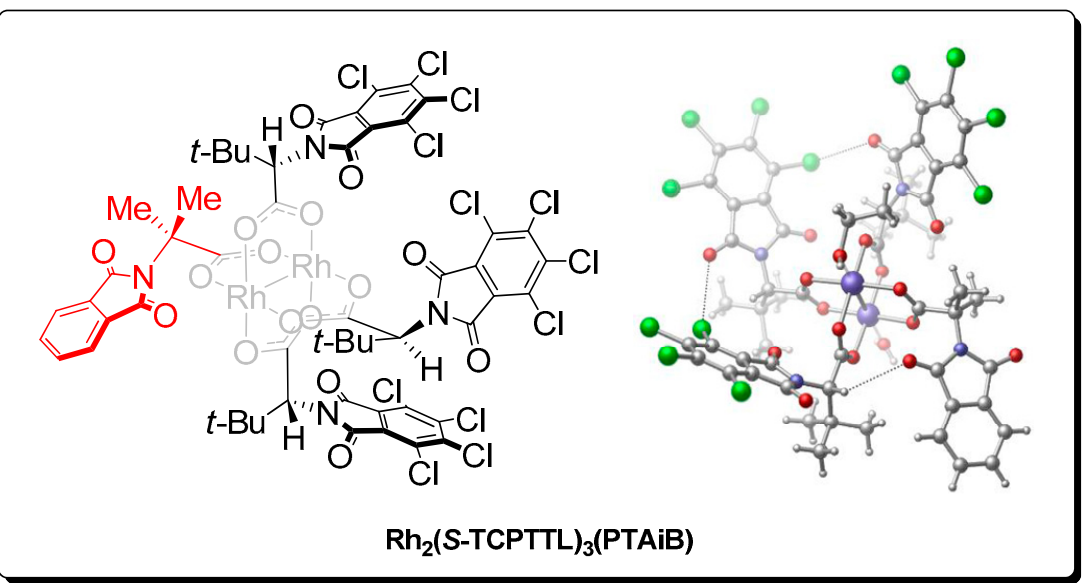

Scheme 10. Enantioselective cyclopropanation reaction of alkenes with $\alpha$-nitro diazoacetophenones and X-ray crystal structure of $\mathrm{Rh}_{2}(\mathrm{~S}$-TCPTTL) 3 (PTAiB). (X-ray crystal structure adapted with permission from Lindsay, V.N.G.; Charette, A.B. ACS Catal. 2012, 2, 1221. Copyright 2017 American Chemical Society).<smiles>CCOC(=O)C(=[W])CC</smiles>

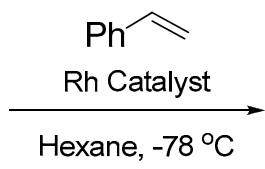<smiles>CCOC(=O)C1(CC)C[Pb]1c1ccccc1</smiles>

$\mathrm{Ph}$

$$
\begin{array}{ll}
\mathrm{Rh}_{2}(\mathrm{~S}-\mathrm{PTTL})_{4} & 79 \% \text { ee } \\
\mathrm{Rh}_{2}(\mathrm{~S}-\mathrm{PTTL})_{3}(\mathrm{TPA}) & 88 \% \text { ee }
\end{array}
$$

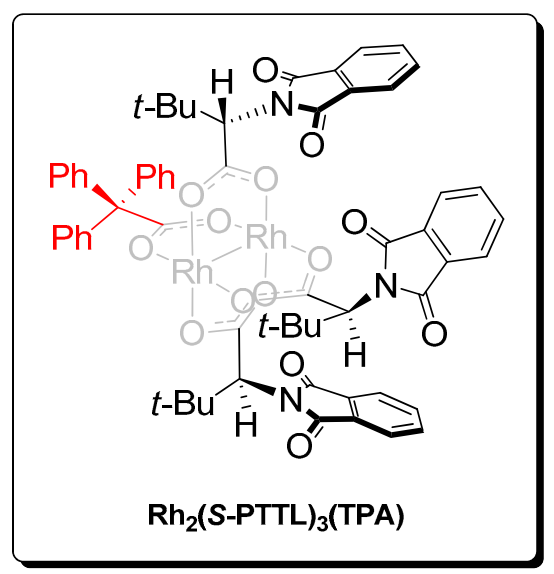

Scheme 11. Enantioselective cyclopropanation of styrene with ethyl $\alpha$-diazobutanoate and structure of $\mathrm{Rh}_{2}(\mathrm{~S}-\mathrm{PTTL})_{3}$ (TPA) according to its X-ray crystal structure [105].

\section{Conclusions}

From the above demonstration, all models proposed to account for the enantioselectivity observed with different dirhodium(II) carboxylate catalysts relied mainly on the obtained X-ray crystal structures 
of these catalysts (except for $\mathrm{Rh}_{2}(S \text {-DOSP })_{4}$ and related prolinate-based complexes). However, due to crystal packing, $\pi$-stacking and/or existence of axial and lattice solvent molecules within the crystal unit cell, the static pose of a catalyst and its chiral ligands portrayed in its $\mathrm{X}$-ray crystal structure does not validate the adaption of the catalyst to the same conformation in solution and during catalysis. In other words, based on the size and the shape of the axial carbene ligand, as well as the reaction solvent used, the metal-carbene intermediate may adapt a different conformation during catalysis to the one observed in its X-ray crystal structure.

In fact, carboxylate ligands contain conformationally mobile units $[13,54,87,98,99]$ which might give the ability to the dirhodium(II) catalyst to adapt its conformation to the particular substrate undergoing the reaction. Then enantioselection mechanisms can mainly originate from the different preferred reaction channels as a function of the different steric interactions taking place between the approaching substrate and the formed dirhodium(II)-carbene complex. This can explain the compatibility of a particular dirhodium(II) carboxylate catalyst with a particular substrate returning high levels of enantioselectivity, while the same catalyst might not retain the same level of enantioselectivity after switching to a different substrate. As a result, catalyst optimization is always necessary in method development to find the optimum catalyst that can return the highest possible level of enantioselectivity with the particular substrate undergoing the reaction. Based on that, researchers must not only limit their focus on the four main conformations of dirhodium(II) carboxylate complexes and an expansion in the considered conformational space is essential.

Even by relying on the catalyst X-ray crystal structures alone to justify the observed enantioselectivity, it is obvious from the demonstration above that dirhodium(II) carboxylate catalysts with $\alpha, \alpha, \alpha, \alpha-, \alpha, \alpha, \alpha, \beta-, \alpha, \alpha, \beta, \beta$ - and $\alpha, \beta, \alpha, \beta$-ligand arrangements were all reported to lead to high levels of enantioselectivity. As a consequence, the original proposal that catalysts with $\alpha, \alpha, \beta, \beta$ - and $\alpha, \beta, \alpha, \beta$-geometries will only result in high enantioselectivity [53] can no longer be considered as valid. In other words, symmetry of the catalyst is not a mandatory prerequisite for achieving high levels of enantioselectivity. Subsequently, the use of high symmetry ligands as the traditional way to produce high symmetry catalysts [53] may not be as essential as previously thought.

All in all, although the knowledge around the structure of dirhodium(II) carboxylate complexes has been expanded dramatically in the last decade, the topic is still in its infancy. With the fast development in X-ray crystallography, computational chemistry and NMR spectroscopy, researchers may prosper in solving the mystery behind this topic. This, in turn, will aid to a great extent in the design of highly stereoselective chiral dirhodium(II) catalysts in the future.

Acknowledgments: The author would like to acknowledge the Chirality research group members at the University of Canberra, Australia, for their support.

Conflicts of Interest: The author declares no conflict of interest.

\section{References}

1. Davies, H.M.L.; Manning, J.R. Catalytic C-H functionalization by metal carbenoid and nitrenoid insertion. Nature 2008, 451, 417-424. [CrossRef] [PubMed]

2. Adly, F.G.; Ghanem, A. Enantiomerically Pure Compounds by Enantioselective Synthetic Chiral Metal Complexes. In Asymmetric Synthesis of Drugs and Natural Products; Nag, A., Ed.; CRC Press: Raton, FL, USA, 2018; in press.

3. Deng, Y.; Qiu, H.; Srinivas, H.D.; Doyle, M.P. Chiral Dirhodium(II) Catalysts for Selective Metal Carbene Reactions. Curr. Org. Chem. 2016, 20,61-81. [CrossRef]

4. Adly, F.G.; Ghanem, A. Chiral Dirhodium (II) Carboxylates and Carboxamidates as Effective Chemzymes in Asymmetric Synthesis of Three-Membered Carbocycles. Chirality 2014, 26, 692-711. [CrossRef] [PubMed]

5. El-Deftar, M.; Adly, F.G.; Gardiner, M.G.; Ghanem, A. Chiral Dirhodium Catalysts: A New Era for Asymmetric Catalysis. Curr. Org. Chem. 2012, 16, 1808-1836. [CrossRef]

6. Trindade, A.F.; Coelho, J.A.S.; Afonso, C.A.M.; Veiros, L.F.; Gois, P.M.P. Fine Tuning of Dirhodium(II): Expolring the Axial Modification. ACS Catal. 2012, 2, 370-383. [CrossRef] 
7. Davies, H.M.L.; Morton, D. Guiding principles for site selective and stereoselective intermolecular C-H functionalization by donor/acceptor rhodium carbenes. Chem. Soc. Rev. 2011, 40, 1857-1869. [CrossRef] [PubMed]

8. Davies, H.M.L.; Bois, J.D.; Yu, J.-Q. C-H Functionalization in organic synthesis. Chem. Soc. Rev. 2011, 40, 1855-1856. [CrossRef] [PubMed]

9. Doyle, M.P.; Duffy, R.; Ratnikov, M.; Zhou, L. Catalytic Carbene Insertion into C-H Bonds. Chem. Rev. 2010, 110, 704-724. [CrossRef] [PubMed]

10. Davies, H.M.L.; Hedley, S.J. Intermolecular reactions of electron-rich heterocycles with copper and rhodium carbenoids. Chem. Soc. Rev. 2007, 36, 1109-1119. [CrossRef] [PubMed]

11. Merlic, C.A.; Zechman, A.L. Selectivity in Rhodium(II) Catalyzed Reactions of Diazo Compounds: Effects of Catalyst ElectoPhilicity, Diazo Substitution and Substrate Substitution. From Chemoselectivity to Enantioselectivity. Synthesis 2003, 34, 1137-1156. [CrossRef]

12. Colacot, T.J. An overview on the application of "Doyle catalysts" in asymmetric cyclopropanation, cyclopropenation and C-H insertion reactions. Proc. Ind. Acad. Sci. (J. Chem. Sci.) 2000, 11, 197-207. [CrossRef]

13. Davies, H.M.L. Dirhodium tetra( $N$-arylsulfonylprolinates) as chiral catalysts for asymmetric transformations of vinyl and aryldiazoacetates. Eur. J. Org. Chem. 1999, 30, 2459-2469. [CrossRef]

14. Davies, H.M.L. Rhodium-stabilized vinylcarbenoid intermediates in organic synthesis. Curr. Org. Chem. 1998, 2, 463-488.

15. Collet, F.; Lescot, C.; Liang, C.; Dauban, P. Studies in catalytic C-H amination involving nitrene C-H insertion. Dalton Trans. 2010, 39, 10401-10413. [CrossRef] [PubMed]

16. Zhang, X.-J.; Yan, M.; Huang, D. Catalyzed addition of diazoacetoacetates to imines: Synthesis of highly functionalized aziridines. Org. Biomol. Chem. 2009, 7, 187-192. [CrossRef] [PubMed]

17. Yamawaki, M.; Tanaka, M.; Abe, T.; Anada, M.; Hashimoto, S. Catalytic enantioselective aziridination of alkenes using chiral dirhodium(II) carboxylates. Heterocycles 2007, 72, 709-721. [CrossRef]

18. Catino, A.J.; Nichols, J.M.; Forslund, R.E.; Doyle, M.P. Efficient Aziridination of Olefins Catalyzed by Mixed-Valent Dirhodium(II,III) Caprolactamate. Org. Lett. 2005, 7, 2787-2790. [CrossRef] [PubMed]

19. Davies, H.M.L.; Denton, J.R. Application of donor/acceptor-carbenoids to the synthesis of natural products. Chem. Soc. Rev. 2009, 38, 3061-3071. [CrossRef] [PubMed]

20. Kubiak, R.W.; Mighion, J.D.; Wilkerson-Hill, S.M.; Alford, J.S.; Yoshidomi, T.; Davies, H.M. Enantioselective Intermolecular C-H Functionalization of Allylic and Benzylic sp3 C-H Bonds Using N-Sulfonyl-1, 2, 3-triazoles. Org. Lett. 2016, 18, 3118-3121. [CrossRef] [PubMed]

21. Doyle, M.P. Perspective on Dirhodium Carboxamidates as Catalysts. J. Org. Chem. 2006, 71, 9253-9260. [CrossRef] [PubMed]

22. Doyle, M.P.; McKervey, M.A.; Ye, T. Modern Catalytic Methods for Organic Synthesis with Diazo Compounds: From Cyclopropanes to Ylides; Wiley: New York, NY, USA, 1998.

23. Hodgson, D.M.; Stupple, P.A.; Pierard, F.Y.T.M.; Labande, A.H.; Johnstone, C. Development of dirhodium(II)-catalyzed generation and enantioselective 1,3-dipolar cycloaddition of carbonyl ylides. Chem.-Eur. J. 2001, 7, 4465-4476. [CrossRef]

24. Doyle, M.P.; Forbes, D.C.; Vasbinder, M.M.; Peterson, C.S. Enantiocontrol in the Generation and Diastereoselective Reactions of Catalytically Generated Oxonium and Iodonium Ylides. Metal-Stabilized Ylides as Reaction Intermediates. J. Am. Chem. Soc. 1998, 120, 7653-7654. [CrossRef]

25. Doyle, M.P.; Hu, W. Macrocycle formation from catalytic metal carbene transformations. Synlett 2001, 2001, 1364-1370. [CrossRef]

26. Doyle, M.P.; Phillips, I.M.; Hu, W. A New Class of Chiral Lewis Acid Catalysts for Highly Enantioselective Hetero-Diels-Alder Reactions: Exceptionally High Turnover Numbers from Dirhodium(II) Carboxamidates. J. Am. Chem. Soc. 2001, 123, 5366-5367. [CrossRef] [PubMed]

27. Doyle, M.P.; Valenzuela, M.; Huang, P. Asymmetric hetero-Diels-Alder reaction catalyzed by dirhodium(II) carboxamidates. Proc. Natl. Acad. Sci. USA 2004, 101, 5391-5395. [CrossRef] [PubMed]

28. Wang, Y.; Wolf, J.; Zavalij, P.; Doyle, M.P. Cationic chiral dirhodium carboxamidates are activated for lewis acid catalysis. Angew. Chem. Int. Ed. 2008, 47, 1439-1442. [CrossRef] [PubMed]

29. Watanabe, N.; Shimada, N.; Anada, M.; Hashimoto, S. Enantio- and diastereoselective hetero-Diels-Alder reactions between 4-methyl-substituted Rawal's diene and aldhydes catalyzed by chiral dirhodium(II) 
carboxamidates: Catalytic asymmetric synthesis of (-)-cis-aerrangis lactone. Tetrahedron Asymmetry 2014, 25, 63-73. [CrossRef]

30. Anada, M.; Washio, T.; Shimada, N.; Kitagaki, S.; Nakajima, M.; Shiro, M.; Hashimoto, S. A new dirhodium(II) carboxamidate complex as a chiral Lewis acid catalyst for enantioselective heteo-Diels-Alder reactions. Angew. Chem. Int. Ed. 2004, 43, 2665-2668. [CrossRef]

31. Hansen, J.H.; Parr, B.T.; Pelphrey, P.; Jin, Q.; Autschbach, J.; Davies, H.M.L. Rhodium(II)-Catalyzed Cross-Coupling of Diazo Compounds. Angew. Chem., Int. Ed. 2011, 50, 2544-2548. [CrossRef] [PubMed]

32. Doyle, M.P.; Protopopova, M.N. New aspects of catalytic asymmetric cyclopropanation. Tetrahedron 1998, 54, 7919-7946. [CrossRef]

33. Davies, H.M.L.; Antoulinakis, E.G. Intermolecular Metal-Catalyzed Carbenoid Cyclopropanations. In Organic Reactions; John Wiley \& Sons Inc.: Hoboken, NJ, USA, 2001; Volume 57, pp. 1-326.

34. Lebel, H.; Marcoux, J.-F.; Molinaro, C.; Charette, A.B. Stereoselective Cyclopropanation Reactions. Chem. Rev. 2003, 103, 977-1050. [CrossRef] [PubMed]

35. Tsuji, J. Modern Rhodium-Catalyzed Organic Reactions; Wiley-VCH: Weinheim, Germany, 2005.

36. Davies, H.M.L.; Bruzinski, P.R.; Lake, D.H.; Kong, N.; Fall, M.J. Asymmetric Cyclopropanations by Rhodium(II) N-(Arylsulfonyl)prolinate-Catalyzed Decomposition of Vinyldiazomethanes in the presence of Alkenes. Practical Enantioselective Synthesis of the four Stereoisomers of 2-Phenylcyclopropan-1-amino Acid. J. Am. Chem. Soc. 1996, 118, 6897-6907. [CrossRef]

37. Reddy, R.P.; Lee, G.H.; Davies, H.M.L. Dirhodium Tetracarboxylate Derived from Adamantylglycine as Chiral Catalyst for Carbenoid Reactions. Org. Lett. 2006, 8, 3437-3440. [CrossRef] [PubMed]

38. Davies, H.M.L.; Venkataramani, C. Dirhodium Tetraprolinate-Catalyzed Asymmetric Cyclopropanations with High Turnover Numbers. Org. Lett. 2003, 5, 1403-1406. [CrossRef] [PubMed]

39. Davies, H.M.L.; Beckwith, E.J. Catalytic enantioselective C-H activation by means of metal-carbenoid-induced C-H insertion. Chem. Rev. 2003, 103, 2861-2903. [CrossRef] [PubMed]

40. Davies, H.M.; Hansen, T. Asymmetric Intermolecular Carbenoid C-H Insertions Catalyzed by Rhodium (II)(S)-N-(p-Dodecylphenyl) sulfonylprolinate. J. Am. Chem. Soc. 1997, 119, 9075-9076. [CrossRef]

41. Davies, H.M.; Hansen, T.; Rutberg, J.; Bruzinski, P.R. Rhodium(II)(S)-N-(arylsulfonyl) prolinate catalyzed asymmetric insertions of vinyl-and phenylcarbenoids into the Si-H bond. Tetrahedron Lett. 1997, 38, 1741-1744. [CrossRef]

42. Davies, H.M.; Stafford, D.G.; Doan, B.D.; Houser, J.H. Tandem asymmetric cyclopropanation/cope rearrangement. A highly diastereoselective and enantioselective method for the construction of 1,4-cycloheptadienes. J. Am. Chem. Soc. 1998, 120, 3326-3331. [CrossRef]

43. Davies, H.M.L. [3 + 4] annulations between Rhodium-stabilized vinylcarbenoids and dienes. In Advances in Cycloaddition, Volume 5; Harmata, M., Ed.; JAI Press INC: Stamford, CT, USA, 1999.

44. Li, Z.; Davies, H.M. Enantioselective C-C Bond Formation by Rhodium-Catalyzed Tandem Ylide Formation/[2,3]-Sigmatropic Rearrangement between Donor/Acceptor Carbenoids and Allylic Alcohols. J. Am. Chem. Soc. 2009, 132, 396-401. [CrossRef] [PubMed]

45. Yue, Y.; Wang, Y.; Hu, W. Regioselectivity in Lewis acids catalyzed X-H (O, S, N) insertions of methyl styryldiazoacetate with benzyl alcohol, benzyl thiol and aniline. Tetrahedron Lett. 2007, 48, 3975-3977. [CrossRef]

46. Hansen, J.H.; Davies, H.M. Vinylogous reactivity of silver(I) vinylcarbenoids. Chem. Sci. 2011, 2, 457-461. [CrossRef]

47. Hansen, J.H.; Gregg, T.M.; Ovalles, S.R.; Lian, Y.; Autschbach, J.; Davies, H.M. On the mechanism and selectivity of the combined C-H activation/Cope rearrangement. J. Am. Chem. Soc. 2011, 133, 5076-5085. [CrossRef] [PubMed]

48. Davies, H.M.; Jin, Q. Highly Diastereoselective and Enantioselective C-H Functionalization of 1, 2-Dihydronaphthalenes: A Combined C-H Activation/Cope Rearrangement Followed by a Retro-Cope Rearrangement. J. Am. Chem. Soc. 2004, 126, 10862-10863. [CrossRef] [PubMed]

49. Davies, H.M.; Hu, B. Ring expansion of tert-butyl 1-vinylcyclopropane-1-carboxylates to alpha-ethylidenebutyrolactones. J. Org. Chem. 1992, 57, 4309-4312. [CrossRef]

50. Pirrung, M.C.; Liu, H.; Morehead, A.T. Rhodium Chemzymes: Michaelis-Menten Kinetics in dirhodium(II) carboxylate-catalyzed carbenoid reactions. J. Am. Chem. Soc. 2002, 124, 1014-1023. [CrossRef] [PubMed] 
51. Nakamura, E.; Yoshikai, N.; Yamanaka, M. Mechanism of C-H Bond Activation/C-C Bond Formation Reaction between Diazo Compound and Alkane Catalyzed by Dirhodium Tetracarboxylate. J. Am. Chem. Soc. 2002, 124, 7181-7192. [CrossRef] [PubMed]

52. Liao, K.; Negretti, S.; Musaev, D.G.; Bacsa, J.; Davies, H.M.L. Site-selective and stereoselective functionalization of inactivated C-H bonds. Nature 2016, 533, 230-234. [CrossRef] [PubMed]

53. Hansen, J.; Davies, H.M.L. High Symmetry Dirhodium(II) Paddlewheel Complexes as Chiral Catalysts. Coord. Chem. Rev. 2008, 252, 545-555. [CrossRef] [PubMed]

54. Lindsay, V.N.G.; Lin, W.; Charette, A.B. Experimental Evidence for the All-Up Reactive Conformation of Chiral Rhodium(II) Carboxylate Catalysts: Enantioselective Synthesis of cis-Cyclopropane $\alpha$-Amino Acids. J. Am. Chem. Soc. 2009, 131, 16383-16385. [CrossRef] [PubMed]

55. Davies, H.M.L.; Bruzinski, P.R.; Fall, M.J. Effect of diazoalkane structure on the stereoselectivity of rhodium(II) (S)-N-(arylsulfonyl)Prolinate catalyzed cyclopropanations. Tetrahedron Lett. 1996, 37, 4133-4136. [CrossRef]

56. Deng, L.; Giessert, A.J.; Gerlitz, O.O.; Dai, X.; Diver, S.T.; Davies, H.M. Metal carbene-promoted sequential transformations for the enantioselective synthesis of highly functionalized cycloheptadienes. J. Am. Chem. Soc. 2005, 127, 1342-1343. [CrossRef] [PubMed]

57. Lian, Y.; Davies, H.M. Rhodium-catalyzed [3 + 2] annulation of indoles. J. Am. Chem. Soc. 2009, 132, 440-441. [CrossRef] [PubMed]

58. Briones, J.F.; Hansen, J.; Hardcastle, K.I.; Autschbach, J.; Davies, H.M.L. Highly enantioselective $\mathrm{Rh}_{2}(\mathrm{~S} \text {-DOSP })_{4}$-catalyzed cyclopropenation of alkynes with styryldiazoacetates. J. Am. Chem. Soc. 2010, 132, 17211-17215. [CrossRef] [PubMed]

59. Parr, B.T.; Green, S.A.; Davies, H.M. Rhodium-catalyzed conversion of furans to highly functionalized pyrroles. J. Am. Chem. Soc. 2013, 135, 4716-4718. [CrossRef] [PubMed]

60. Davies, H.M.; Hansen, T.; Churchill, M.R. Catalytic asymmetric C-H activation of alkanes and tetrahydrofuran. J. Am. Chem. Soc. 2000, 122, 3063-3070. [CrossRef]

61. Davies, H.M.; Ren, P. Catalytic Asymmetric C-H Activation of Silyl Enol Ethers as an Equivalent of an Asymmetric Michael Reaction. J. Am. Chem. Soc. 2001, 123, 2070-2071. [CrossRef] [PubMed]

62. Davies, H.M.; Venkataramani, C. Catalytic Enantioselective Synthesis of $\beta 2$-Amino Acids. Angew. Chem. Int. Ed. 2002, 41, 2197-2199. [CrossRef]

63. Davies, H.M.; Walji, A.M. Direct Synthesis of (+)-Erogorgiaene through a Kinetic Enantiodifferentiating Step. Angew. Chem. Int. Ed. 2005, 44, 1733-1735. [CrossRef] [PubMed]

64. Davies, H.M.L.; Manning, J.R. C-H Activation as a Strategic Reaction: Enantioselective Synthesis of 4-Substituted Indoles. J. Am. Chem. Soc. 2006, 128, 1060-1061. [CrossRef] [PubMed]

65. Davies, H.M.L.; Dai, X.; Long, M.S. Combined C-H Activation/Cope Rearrangement as a Strategic Reaction in Organic Synthesis: Total Synthesis of (-)-Colombiasin A and (-)-Elisapterosin B. J. Am. Chem. Soc. 2006, 128, 2485-2490. [CrossRef] [PubMed]

66. Davies, H.M.L.; Lee, G.H. Dirhodium(II) Tetra(N-(dodecylbenzenesulfonyl)prolinate) Catalyzed Enantioselective Cyclopropenation of Alkynes. Org. Lett. 2004, 6, 1233-1236. [CrossRef] [PubMed]

67. Lian, Y.; Davies, H.M. Combined C-H functionalization/Cope rearrangement with vinyl ethers as a surrogate for the vinylogous Mukaiyama aldol reaction. J. Am. Chem. Soc. 2011, 133, 11940-11943. [CrossRef] [PubMed]

68. Davies, H.M.L.; Townsend, R.J. Catalytic asymmetric cyclopropanation of hetereoaryldiazoacetates. J. Org. Chem. 2001, 66, 6595-6603. [CrossRef] [PubMed]

69. Davies, H.M.; Hutcheson, D.K. Enantioselective synthesis of vinylcyclopropanes by rhodium(II)-catalyzed decomposition of vinyldiazomethanes in the presence of alkenes. Tetrahedron Lett. 1993, 34, 7243-7246. [CrossRef]

70. Davies, H.M.L.; Nagashima, T.; Klino, J.L. Stereoselectivity of Methyl Aryldiazoacetate cyclopropanations of 1,1-diarylethylene. Asymmetric synthesis of cyclopropyl analouge of Tamoxifen. Org. Lett. 2000, 2, 823-826. [CrossRef] [PubMed]

71. Davies, H.M.L.; Panaro, S.A. Novel dirhodium tetraprolinate catalysts containing bridging prolinate ligands for asymmetric carbenoid reactions. Tetrahedron Lett. 1999, 40, 5287-5290. [CrossRef]

72. Davies, H.M.L.; Kong, N. Synthesis and evaluation of a novel dirhodium tetraprolinate catalyst containing bridging prolinate ligands. Tetrahedron Lett. 1997, 38, 4203-4206. [CrossRef] 
73. Qin, C.; Boyarskikh, V.; Hansen, J.H.; Hardcastle, K.I.; Musaev, D.G.; Davies, H.M.L. D2-Symmetric Dirhodium Catalyst Derived from a 1,2,2-triarylcyclopropanecarboxylate ligand: Design, Synthesis and Application. J. Am. Chem. Soc. 2011, 133, 19198-19204. [CrossRef] [PubMed]

74. Qin, C.; Davies, H.M.L. Enantioselective synthesis of 2-arylbicyclo[1.1.0]butane carboxylates. Org. Lett. 2013, 15, 310-313. [CrossRef] [PubMed]

75. Qin, C.; Davies, H.M.L. $\mathrm{Rh}_{2}(R \text {-TPCP })_{4}$-catalyzed Enantioselective [3 + 2]-cycloaddition between nitrones and vinyldiazoacetates. J. Am. Chem. Soc. 2013, 135, 14516-14519. [CrossRef] [PubMed]

76. Hashimoto, S.; Watanabe, N.; Sato, T.; Shiro, M.; Ikegami, S. Enhancement of Enantioselectivity in Intramolecular C-H Insertion Reactions of $\alpha$-Diazo- $\beta$-Keto Esters Catalyzed by Chiral Dirhodium(II) Carboxylates. Tetrahedron Lett. 1993, 34, 5109-5112. [CrossRef]

77. Tsutsui, H.; Abe, T.; Nakamura, S.; Anada, M.; Hashimoto, S. Practical Synthesis of Dirhodium(II) Tetrakis[N-phthaloyl-(S)-tert-leucinate]. Chem. Pharm. Bull. 2005, 53, 1366-1368. [CrossRef] [PubMed]

78. DeAngelis, A.; Dmitrenko, O.; Yap, G.P.A.; Fox, J.M. Chiral Crown Conformation of Rh ${ }_{2}(\mathrm{PTTL})_{4}$ : Enantioselective Cyclopropanation with $\alpha$-Alkyl- $\alpha$-diazoesters. J. Am. Chem. Soc. 2009, 131, 7230-7231. [CrossRef] [PubMed]

79. Minami, K.; Saito, H.; Tsutsui, H.; Nambu, H.; Anada, M.; Hashimoto, S. Highly Enantio- and Diastereoselective Construction of 1,2-Disubstituted Cyclopentane Compounds by Dirhodium(II) Tetrakis[Nphthaloyl-(S)-tert-leucinate]-Catalyzed C-H Insertion Reactions of $\alpha$-Diazo Esters. Adv. Synth. Catal. 2005, 347, 1483-1487. [CrossRef]

80. Awata, A.; Arai, T. Catalytic Asymmetric Cyclopropanation with Diazooxindole. Synlett 2013, 24, $29-32$.

81. Lindsay, V.N.G.; Nicolas, C.; Charette, A.B. Asymmetric Rh(II)-Catalyzed Cyclopropanation of Alkenes with Diacceptor Diazo Compounds: p-Methoxyphenyl Ketone as a General Stereoselectivity Controlling Group. J. Am. Chem. Soc. 2011, 133, 8972-8981. [CrossRef] [PubMed]

82. Goto, T.; Takada, K.; Anada, M.; Ando, K.; Hashimoto, S. Enantio- and diastereoselective cyclopropanation with tert-butyl $\alpha$-diazopropionate catalyzed by dirhodium(II) tetrakis[ $N$-tetrabromophthaloyl(S)-tert-Leucinate]. Tetrahedron Lett. 2011, 52, 4200-4203. [CrossRef]

83. Goto, T.; Takada, K.; Shimada, N.; Nambu, H.; Anada, M.; Shiro, M.; Ando, K.; Hashimoto, S. Highly enantioselective cyclopropenation reaction reaction of 1-Alkynes with $\alpha$-alkyl- $\alpha$-diazoesters catalyzed by rhodium(II) carboxylates. Angew. Chem. Int. Ed. 2011, 50, 6803-6808. [CrossRef] [PubMed]

84. Xu, X.; Deng, Y.; Yim, D.N.; Zavalij, P.Y.; Doyle, M.P. Enantioselective cis- $\beta$-lactam synthesis by intramolecular $\mathrm{C}-\mathrm{H}$ functionalization from enoldiazoacetamides and derivative donor-acceptor cyclopropenes. Chem. Sci. 2015, 6, 2196-2201. [CrossRef] [PubMed]

85. Tsutsui, H.; Matsuura, M.; Makino, K.; Nakamura, S.; Nakajima, M.; Kitagaki, S.; Hashimoto, S. Enantioselective Tandem Formation and [2,3]-Sigmatropic Rearrangement of Cyclic Propargylic Oxonium Ylides Catalyzed by Dirhodium(II) Tetrakis[Naphthaloyl-(S)-tert-leucinate]. Isr. J. Chem. 2001, 41, 283-295. [CrossRef]

86. Watanabe, N.; Ohtake, Y.; Hashimoto, S.; Shiro, M.; Ikegami, S. Asymmetric creation of quaternary carbon centers by enantiotopically selective aromatic C-H insertion catalyzed by chiral dirhodium(II) carboxylates. Tetrahedron Lett. 1995, 36, 1491-1494. [CrossRef]

87. DeAngelis, A.; Boruta, D.T.; Lubin, J.-B.; Plampin, J.N.; Yap, G.P.A.; Fox, J.M. The chiral crown conformation in paddlewheel complexes. Chem. Commun. 2010, 46, 4541-4543. [CrossRef] [PubMed]

88. Nadeau, E.; Ventura, D.L.; Brekan, J.A.; Davies, H.M.L. Controlling factors for C-H functionalization versus cyclopropanation of dihydronaphthalenes. J. Org. Chem. 2010, 75, 1927-1939. [CrossRef] [PubMed]

89. Adly, F.G.; Maddalena, J.; Ghanem, A. $\mathrm{Rh}_{2}(S-1,2-N T T L)_{4}$ : A Novel $\mathrm{Rh}_{2}(\text { S-PTTL })_{4}$ Analog With Lower Ligand Symmetry for Asymmetric Synthesis of Chiral Cyclopropylphosphonates. Chirality 2014, 26, 764-774. [CrossRef] [PubMed]

90. Kitagaki, S.; Anada, M.; Kataoka, O.; Matsuno, K.; Umeda, C.; Watanabe, N.; Hashimoto, S. Enantiocontrol in Tandem Carbonyl Ylide Formation and Intermolecular 1,3-Dipolar Cycloaddition of $\alpha$-Diazo Ketones Mediated by Chiral Dirhodium(II) Carboxylate Catalyst. J. Am. Chem. Soc. 1999, 121, 1417-1418. [CrossRef]

91. Denton, J.R.; Sukumaran, D.; Davies, H.M.L. EnantioSelective Synthesis of trifluoromethyl-Substituted Cyclopropanes. Org. Lett. 2007, 9, 2625-2628. [CrossRef] [PubMed]

92. Denton, J.R.; Cheng, K.; Davies, H.M.L. Stereoselective construction of nitrile-substituted cyclopropanes. Chem. Commun. 2008, 1238-1240. [CrossRef] [PubMed] 
93. Denton, J.R.; Davies, H.M.L. Enantioselective reactions of donor/acceptor carbenoids derived from $\alpha$-aryl- $\alpha$-diazoketones. Org. Lett. 2009, 11, 787-790. [CrossRef] [PubMed]

94. Chepiga, K.M.; Qin, C.; Alford, J.S.; Chennamadhavuni, S.; Gregg, T.M.; Olson, J.P.; Davies, H.M.L. Guide to enantioselective dirhodium(II)-catalyzed cyclopropanation with aryldiazoacetates. Tetrahedron 2013, 69, 5765-5771. [CrossRef] [PubMed]

95. Briones, J.F.; Davies, H.M.L. $\mathrm{Rh}_{2}(\mathrm{~S}-\mathrm{PTAD})_{4}$ catalyzed asymmetric cyclopropanation of aryl alkynes. Tetrahedron 2011, 67, 4313-4317. [CrossRef]

96. Wang, H.; Guptill, D.M.; Varela-Alvarez, A.; Musaev, D.G.; Davies, H.M.L. Rhodium-catalyzed enantioselective cyclopropanation of electron deficient alkenes. Chem. Sci. 2013, 4, 2844-2850. [CrossRef] [PubMed]

97. Werlé, C.; Goddard, R.; Philipps, P.; Farès, C.; Fürstner, A. Stabilization of a Chiral Dirhodium Carbene by Encapsulation and a Discussion of the Stereochemical Implications. Angew. Chem. Int. Ed. 2016, 55, 10760-10765. [CrossRef] [PubMed]

98. Adly, F.G.; Gardiner, M.G.; Ghanem, A. Design and Synthesis of Novel Chiral Dirhodium(II) Carboxylate Complexes for Asymmetric Cyclopropanation Reactions. Chem.-Eur. J. 2016, 22, 3447-3461. [CrossRef] [PubMed]

99. Mattiza, J.T.; Fohrer, J.G.G.; Duddeck, H.; Gardiner, M.G.; Ghanem, A. Optimizing dirhodium(II) tetrakiscarboxylates as chiral NMR auxiliaries. Org. Biomol. Chem. 2011, 9, 6542-6550. [CrossRef] [PubMed]

100. Gardiner, M.G.; Ghanem, A. X-ray crystal structures of bis $($ EtOAc $)$ and $(\mathrm{MeOH})\left(\mathrm{H}_{2} \mathrm{O}\right)$ adducts of $\mathrm{Rh}_{2}(\text { S-PTPA })_{4}$ complex. Unpublished work, 2010.

101. Müller, P.; Ghanem, A. Rh(II)-Catalyzed Enantioselective Cyclopropanation of Olefins with Dimethyl Malonate via in Situ Generated Phenyliodonium Ylide. Org. Lett. 2004, 6, 4347-4350. [CrossRef] [PubMed]

102. Ghanem, A.; Gardiner, M.G.; Williamson, R.M.; Müller, P. First X-ray Structure of a N-Naphthaloyl-Tethered Chiral Dirhodium(II) Complex: Structural Basis for Tether Substitution Improving Asymmetric Control in Olefin Cyclopropanation. Chem.-Eur. J. 2010, 16, 3291-3295. [CrossRef] [PubMed]

103. Adly, F.G.; Ghanem, A. Polymer monolith-supported dirhodium(II)-catalyzed continuous flow cyclopropanation in capillary format. Tetrahedron Lett. 2016, 57, 852-857. [CrossRef]

104. Lindsay, V.N.G.; Charette, A.B. Design and Synthesis of Chiral Heteroleptic Rhodium(II) Carboxylate Catalysts: Experimental Investigations of Halogen Bond Rigidification Effects in Asymmetric Cyclopropanation. ACS Catal. 2012, 2, 1221-1225. [CrossRef]

105. Boruta, D.T.; Dmitrenko, O.; Yap, G.P.A.; Fox, J.M. $\mathrm{Rh}_{2}$ (S-PTTL) 3 TPA-A mixed-ligand dirhodium(II) catalyst for enantioselective reactions of $\alpha$-alkyl- $\alpha$-diazoesters. Chem. Sci. 2012, 3, 1589-1593. [CrossRef] [PubMed] 